\title{
Source apportionment and impact of long-range transport on carbonaceous aerosol particles in Central Germany during HCCT-2010
}

5 Laurent Poulain ${ }^{1}$, Benjamin Fahlbusch ${ }^{1,}$, Gerald Spindler ${ }^{1}$, Konrad Müller ${ }^{1}$, Dominik van Pinxteren ${ }^{1}$, Zhijun $\mathrm{Wu}^{1, * *}$, Yoshiteru Iinuma ${ }^{1, * * *}$, Wolfram Birmili ${ }^{1{ }^{* * * *}}$, Alfred Wiedensohler ${ }^{1}$, Hartmut Herrmann ${ }^{1}$

${ }^{1}$ Leibniz Institut für Troposphärenforschung, (TROPOS), Leipzig, 04318, Germany

${ }^{*}$ Now at Eurofins, Friedrichsdorf, 61381, Germany

** Now at College of Environment Sciences and Engineering, Peking University, Beijing, 100871, China

$10^{* * *}$ Now at: Okinawa Institute of Science and Technology Graduate University (OIST), Okinawa, 904-0495, Japan

**** Now at: Umweltbundesamt (UBA), Berlin, 14195, Germany

Correspondence to: Hartmut Herrmann (herrmann@tropos.de) and Laurent Poulain (poulain@tropos.de) 
SI-1 Instrumental set-up and analytical methods

Table SI-1: Instrumentation used for trace gas measurements.

\begin{tabular}{|c|c|c|c|c|c|}
\hline parameter & Type & $\begin{array}{c}\text { Time } \\
\text { resolution }\end{array}$ & $\begin{array}{l}\text { Detection } \\
\text { limits }\end{array}$ & $\begin{array}{c}\text { Technique/Method/size } \\
\text { cutting }\end{array}$ & $\begin{array}{l}\text { Measured } \\
\text { species }\end{array}$ \\
\hline \multicolumn{6}{|c|}{ Gas samplers * } \\
\hline Ozone & $\begin{array}{l}\text { TE49C-TL } \\
\text { (Thermo Fischer } \\
\text { Scientific Inc.) }\end{array}$ & $<2 \min$ & $1 \mathrm{ppb}$ & UV-absorption & Ozone \\
\hline $\begin{array}{c}\mathrm{NO}_{\mathrm{x}} \\
\left(\mathrm{NO} / \mathrm{NO}_{2}\right)\end{array}$ & $\begin{array}{c}\text { TE42S Thermo } \\
\text { (Fischer Scientific } \\
\text { Inc.) }\end{array}$ & $0.5 \mathrm{~min}$ & $0.5 \mathrm{ppb}$ & Chemiluminescence & $\mathrm{NO}$ and $\mathrm{NO}_{2}$ \\
\hline $\mathrm{SO}_{2}$ & $\begin{array}{c}\text { TE43C-TL } \\
\text { (Thermo Fischer } \\
\text { Scientific Inc.) }\end{array}$ & $<2 \min$ & $0.2 \mathrm{ppb}$ & UV-fluorescence & $\mathrm{SO}_{2}$ \\
\hline $\mathrm{CO}$ & $\begin{array}{c}\text { ML } 9830 \text { (Monitor } \\
\text { Europe) }\end{array}$ & & & & \\
\hline $\begin{array}{l}\text { Water } \\
\text { soluble } \\
\text { gases }\end{array}$ & MARGA & 1 hour & & $\begin{array}{c}\text { Denuder sampling for } \\
\text { gases and online IC } \\
\text { analysis }\end{array}$ & $\begin{array}{c}\mathrm{NH}_{3}, \mathrm{HCl}, \\
\mathrm{HONO} \mathrm{HNO}_{3}, \\
\mathrm{SO}_{2}\end{array}$ \\
\hline VOC & & $\begin{array}{c}2 \text { h during } \\
\text { IOPs }\end{array}$ & & $\begin{array}{c}\text { Thermal desorption GC- } \\
\text { FID }\end{array}$ & $\begin{array}{c}26 \mathrm{NMHC}(\mathrm{C} 2- \\
\mathrm{C} 8)\end{array}$ \\
\hline
\end{tabular}

${ }^{*} \mathrm{SO}_{2}$ and $\mathrm{NO}_{\mathrm{x}}$ analyzers were calibrated using test gas cylinders (air liquid, Germany), $\mathrm{NO}_{2}$ by a gas-phase-titration system

20 (Sycos K/GPT; Ansyco GmbH, Germany), and an $\mathrm{O}_{3}$ analyzer by the calibrator system TE49PS 
SI-2 Sample preparation and chemical analysis of the 5-stage Berner-impactor

25

Samples of the 5-stage Berner-impactor were collected on aluminum foils (Table SI-2). Each foil was weighed after a $72 \mathrm{~h}$ equilibration under constant temperature $\left(20 \pm 1{ }^{\circ} \mathrm{C}\right)$ and humidity $(50 \pm 5 \%)$ before and after collection using an electronic microbalance (UMT 2, Mettler Toledo, Switzerland) with a reading precision of $0.1 \mu \mathrm{g}$ and a reproducibility of $1 \mu \mathrm{g}$. A part of the impactor foils was extracted with $1.5 \mathrm{ml}$ MilliQ-water ( $>18.2 \mathrm{M} \Omega \mathrm{cm} ; 15 \mathrm{~min}$ shaker, $15 \mathrm{~min}$ ultrasonic bath, $15 \mathrm{~min}$

30 shaker). Sample extracts were then filtered through a $0.45 \mu \mathrm{m}$ disposable syringe filter to remove insoluble materials prior to ion analysis by ion chromatography (ICS300, Dionex, USA) for cations (Column CS16, eluent methane sulfonic acid) and anions (Column AS18, eluent $\mathrm{KOH}$ ). Calibrations were carried out daily using a four point's standard diluted from a stock solution (Fluka, Switzerland). The detection limits for all ions measured by conductivity detection were within $0.1 \mathrm{mg} \mathrm{l}^{-1}$, except for sulfate and nitrate $\left(0.2 \mathrm{mg} \mathrm{l}^{-1}\right)$. Nitrite was detected using UV/VIS detection (VWD-1, Dionex) with a detection

35 limit of $0.1 \mathrm{mg} \mathrm{l}^{-1}$, which leads to a general detection limit ranging between 0.005 and $0.05 \mu \mathrm{g} \mathrm{m}^{-3}$ depending on the sampling volume and species. Blank corrections were made according to the analyzed field blank impactor foils. The organic carbon (OC) and elemental carbon (EC), in sum total carbon (TC), analyses were made using a carbon analyzer type C-mat 5500 with a non-disperse infrared detector (NDIR) (Ströhlein, Germany) based on a modification of the German VDI guideline 2465 (Gnauk et al., 2008). Finally, sugars and anhydrosaccharides (e.g. levoglucosan, galactosan and mannosan) were analyzed

40 from the water extract prepared for ion chromatography using an ICS3000 system (Dionex, U.S.A.) equipped with a pulsed amperometric detector (Engling et al., 2006; Iinuma et al., 2009).

Table SI-2: Berner-impactor measurements periods associated to full cloud events (FCE) and non-cloud events (NCE) taken during the sampling periods. More details on the FCEs and NCEs can be found in Tilgner et al. (2014).

\begin{tabular}{|c|c|c|c|c|c|c|c|c|c|c|c|}
\hline & $\begin{array}{c}\text { FCE } \\
1.1\end{array}$ & $\begin{array}{c}\text { NCE } \\
0.1\end{array}$ & $\begin{array}{l}\mathrm{NCE} \\
0.2\end{array}$ & $\begin{array}{l}\text { FCE } \\
11.2\end{array}$ & $\begin{array}{l}\text { FCE } \\
11.3\end{array}$ & $\begin{array}{l}\text { FCE } \\
12.1\end{array}$ & $\begin{array}{l}\text { FCE } \\
13.1\end{array}$ & $\begin{array}{l}\text { FCE } \\
13.3\end{array}$ & $\begin{array}{l}\text { FCE } \\
22.1\end{array}$ & $\begin{array}{c}\text { NCE } \\
0.3\end{array}$ & $\begin{array}{c}\text { FCE } \\
26\end{array}$ \\
\hline & 14.09 .2 & 15.09 .2 & 20.09 .2 & 01.10 .2 & 02.10 .2 & 05.10 .2 & 05.10 .2 & 06.10 .2 & 19.10 .2 & 21.10 .2 & 24.10 .2 \\
\hline & 010 & 010 & 010 & 010 & 010 & 010 & 010 & 010 & 010 & 010 & 010 \\
\hline Starting time & $11: 00$ & $18: 00$ & $11: 25$ & $22: 30$ & $14: 30$ & $08: 30$ & $19: 15$ & $12: 15$ & $21: 30$ & $14: 15$ & 01:30 \\
\hline & 15.09 .2 & 15.09 .2 & 20.09 .2 & 02.10 .2 & 02.10 .2 & 05.10 .2 & 06.10 .2 & 07.10 .2 & 20.10 .2 & 21.10 .2 & 24.10 .2 \\
\hline & 010 & 010 & 010 & 010 & 010 & 010 & 010 & 010 & 010 & 010 & 010 \\
\hline Stopping time & 02:00 & $23: 30$ & $20: 30$ & 05:30 & $19: 30$ & $13: 00$ & $04: 30$ & $03: 15$ & 03:30 & $22: 15$ & $11: 45$ \\
\hline $\begin{array}{c}\text { Back-trajectory } \\
\text { Cluster }\end{array}$ & $\mathrm{C} 1$ & $\mathrm{C} 1$ & $\mathrm{C} 1$ & $\mathrm{C} 3$ & $\mathrm{C} 3$ & $\begin{array}{l}\text { C4 to } \\
\text { C3 }\end{array}$ & $\mathrm{C} 3$ & $\begin{array}{l}\text { C3 to } \\
\text { C4 }\end{array}$ & $\mathrm{C} 1$ & $\mathrm{C} 1$ & $\begin{array}{c}\text { C3 to } \\
\text { C2 via } \\
\text { C1 }\end{array}$ \\
\hline
\end{tabular}

45 


\section{SI-3 AMS data validation}

Prior to mass closure analysis, conversion of the particle number concentration of the T-MPSS to the volume concentration was made assuming spherical particles, and to the mass concentration using a time dependent density estimated using the equation of Salcedo et al. (2006) and based on the measured $\mathrm{PM}_{1}$ chemical composition as previously described in Poulain et al. (2014). A good correlation was obtained (slope of 0.93, $\mathrm{R}^{2}=0.94$, Fig. SI-1), indicating that non-detected compounds (i.e. AMS refractory compounds except $\mathrm{eBC}$ ) do not significantly contribute to the $\mathrm{PM}_{1}$ mass concentration.

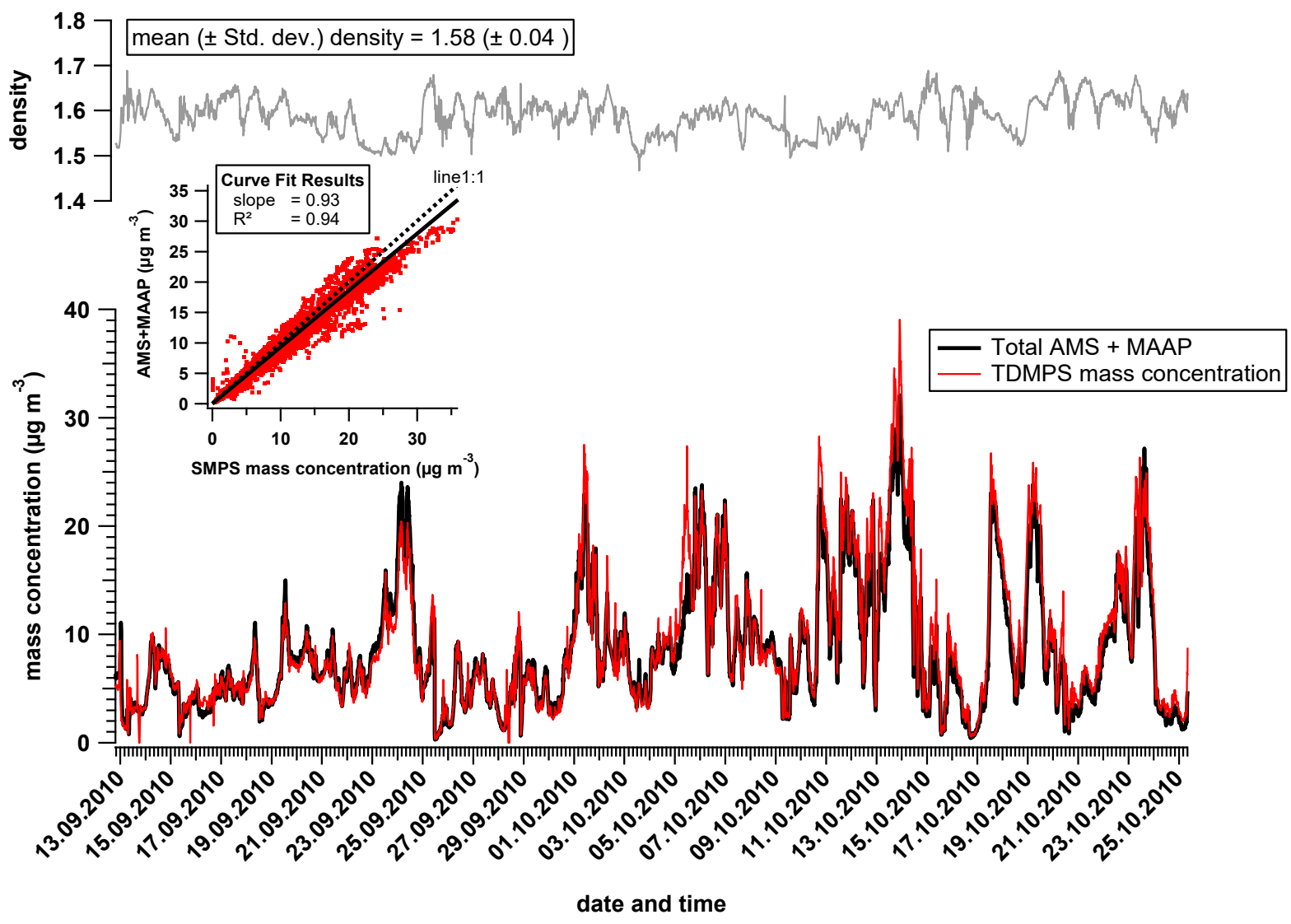

55 Figure SI-1: Mass closure between online aerosol chemical composition (AMS and MAAP) and TDMPS estimated mass concentration (bottom and insert). Time and chemical dependent density (top) was used to convert the volume concentation of the TDMPS into mass concentration. The correlation curve (black line) was calculated using the least orthogonal distance fit method

The MARGA (PM $\mathrm{PM}_{10}$, Fig. SI-2 \& SI-3) and Berner impactor $\mathrm{PM}_{1.2}$ (sum of the three first stages, Fig. SI-4) mass concentration of ammonium, nitrate, and sulfate also present an excellent correlation with the AMS measurements regarding individual instrumental limitations. This includes the limited number of samples and the reduced sampling time of the Berner impactor, as well as the specific upper size cutting (near-PM $\mathrm{P}_{1}$ for the AMS, $\mathrm{PM}_{1.2}$ for the Berner impactor, and PM 10 for MARGA). 
Moreover, the presence of different nitrate salts can also explain the discrepancy between AMS and MARGA (see discussion on main text).
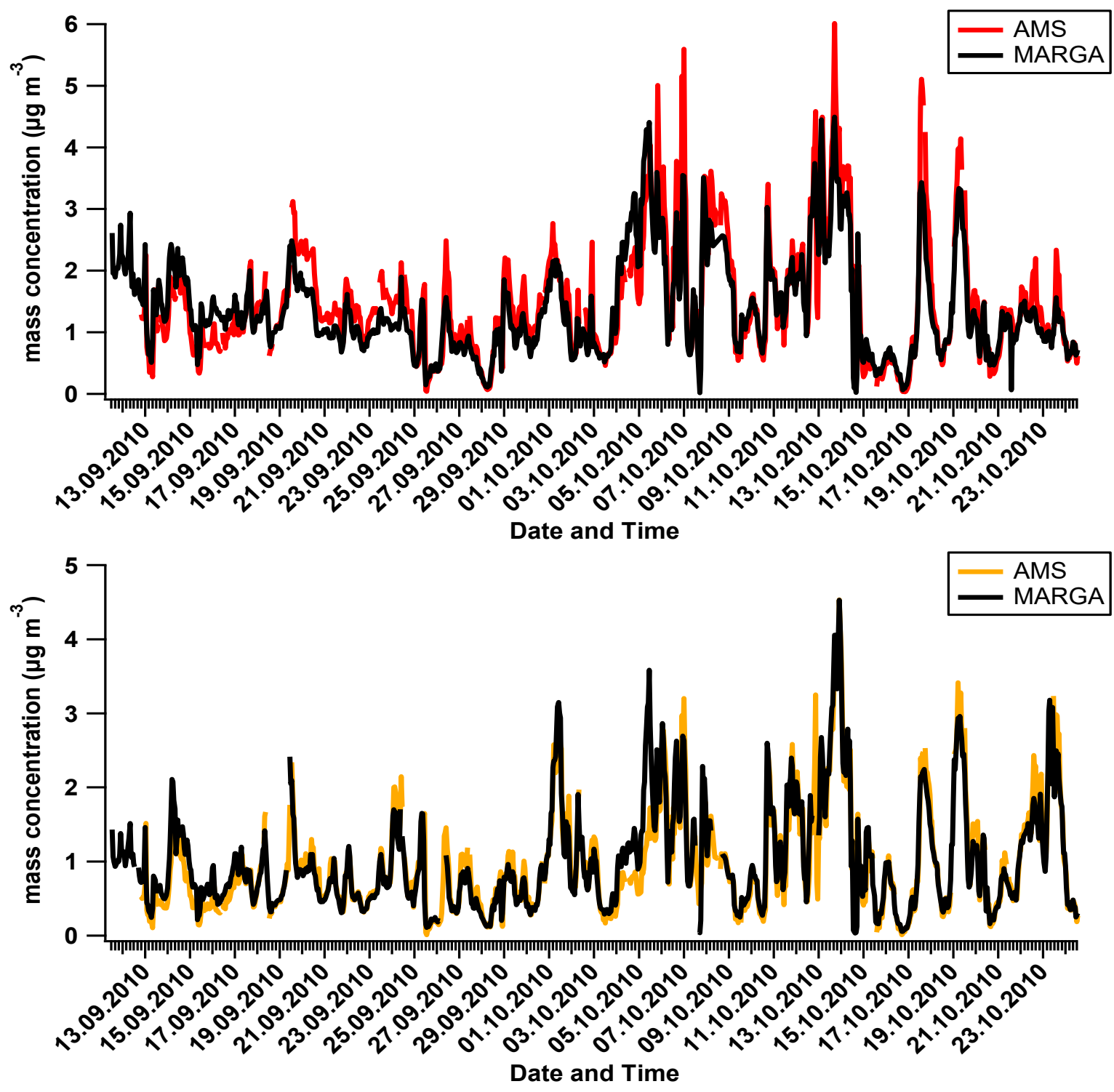

Figure SI-2: Sulfate (top) and ammonium (bottom) time series measured by AMS (colored line) and MARGA (black line). 

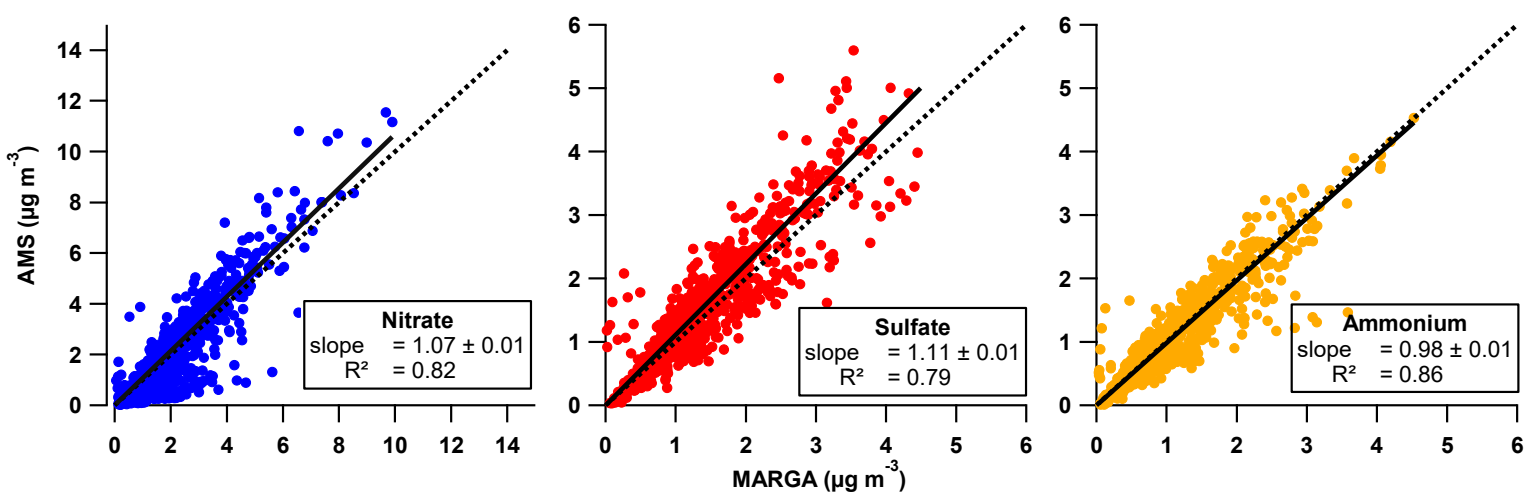

70 Figure SI-3: Scatter plots of the nitrate, sulfate, and ammonium mass concentrations measured by AMS and MARGA. The correlation curves (red lines) were calculated using the least orthogonal distance fit method.
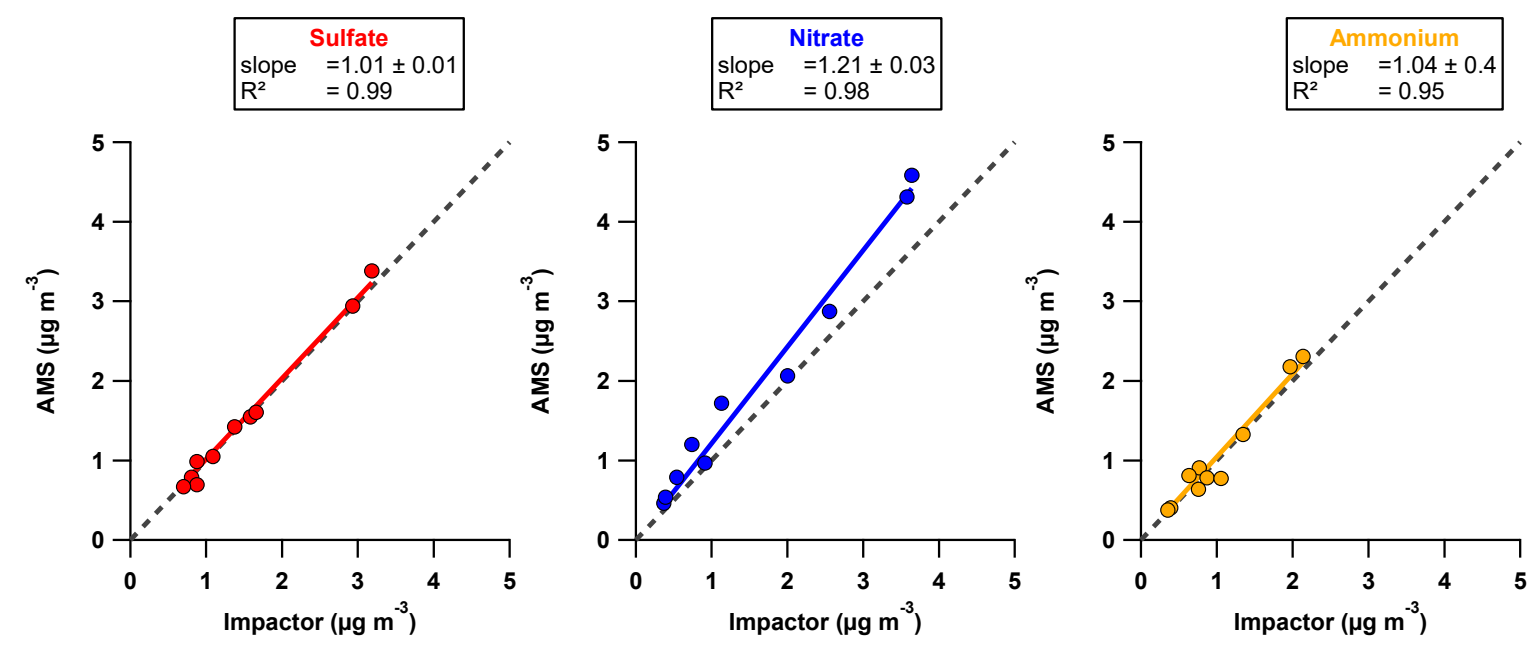

75 Figure SI-4: Comparison of AMS and impactor measurements (stages 1-3, i.e. PM1.2) during the different cloud and non-cloud events (see text for details on sampling periods). The correlation curves (red lines) were calculated using the least orthogonal distance fit method 


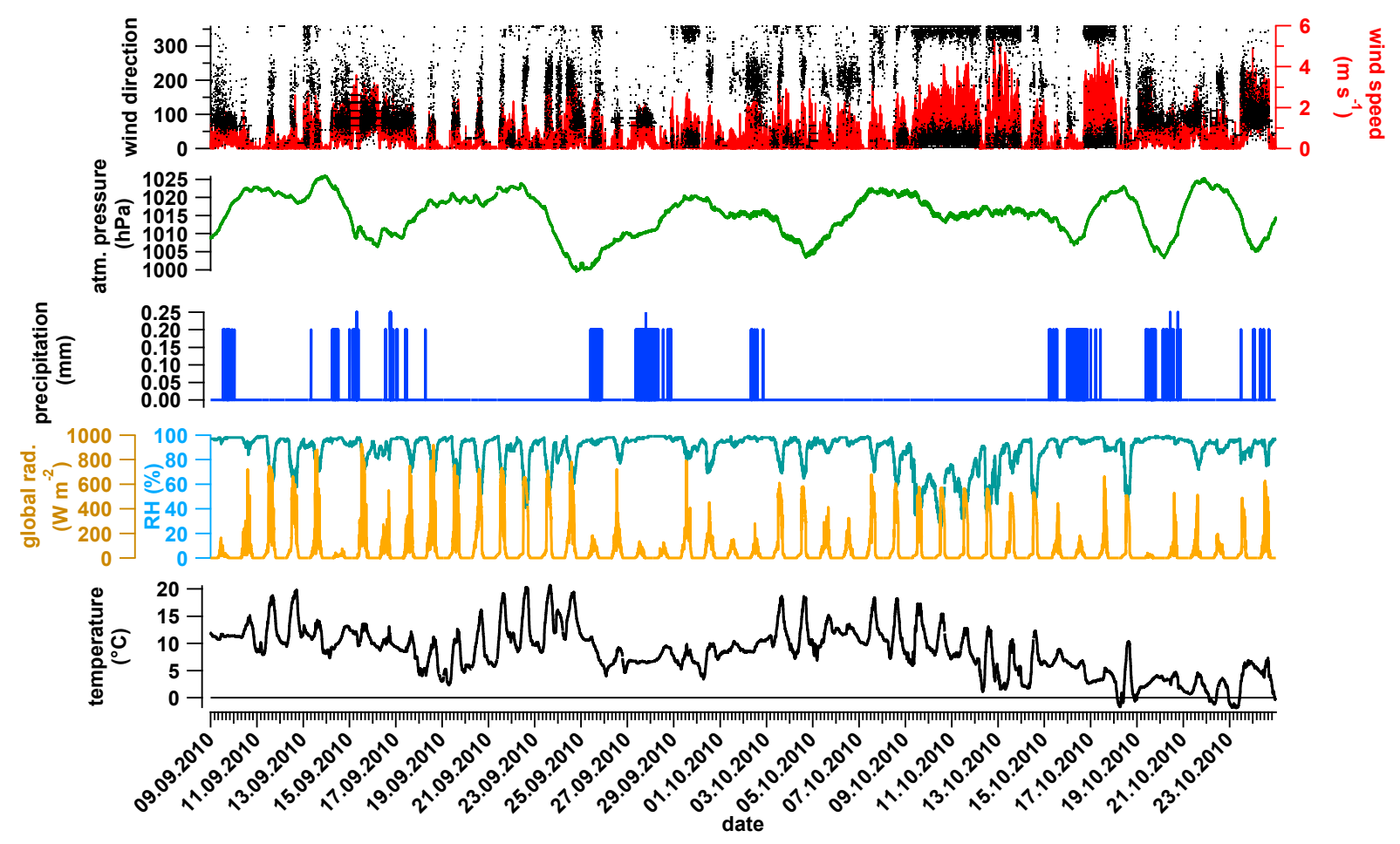

Figure SI-5: Overview of the meteorological conditions during the sampling period. 


\section{SI-5 Organic aerosol source apportionment}

Source apportionment was performed on the high-resolution organic mass spectra dataset using the Multi-linear Engine (ME2) model developed by Paatero (1999) and using the Source Finder tool Sofi4.9 (Canonaco et al., 2013) developed at the Paul Scherrer Institute (Switzerland). The source apportionment was made following the recommendation of Crippa et al. (2014):

90 for the first time a non-constrained model approach was investigated and since primary factors were not properly resolved in this first model, a partially constrained approach was investigated during a second time.

\section{SI-5-1 Non-constrained model (PMF)}

In the non-constrained ME-2 model, solutions were investigated in a range from 2 to 10 factors, each within 20 seeds (Fig. SI-

95 6). The best solution was obtained for the 4-factors solution and the different factors were identified as primary OA (POA; 20 $\%$ of the total OA), semi-volatile OA (SV-OOA; $17 \%$ ), and 2 OOAs (named LV-OOA1 and LV-OOA2; $28 \%$ and 34 \%, respectively) (Fig. SI-7). The POA factor was identified based on its low oxidation $(\mathrm{O}: \mathrm{C}=0.27)$ and presence of typical tracers from two primary OAs (Hydrocarbon-like OA (HOA) with the $\mathrm{m} / \mathrm{z} 55$ and 57 and Biomass Burning OA (BBOA) with m/z 60 and 73). Moreover, similarity between its diurnal profile and the ones of the different anthropogenic emission tracers (eBC,

$100 \mathrm{CO}$, and $\mathrm{NO}_{2}$, Fig. SI-8) confirm its primary origin. The presence of the BBOA tracers (m/z 60 and m/z 73) on the POA mass spectra indicates a dominant biomass burning influence on the primary OA sources. Increasing the number of factors to 5 leads to an additional split of the POA factor without providing clear HOA and BBOA factors. However, it is interesting to note the relative stability of the two OOA mass spectra in the range from 3- to 5-factors (Fig. SI-9). Changes on their individual concentrations highlight the influence of the additional splitting when increasing the number of factor solutions. This stability

105 indicates that these two factors can easily be extracted from the OA matrix by the model and therefore, their identification can be considered as quite robust in the range of 3- to 5-factors solutions. By increasing the factor's number above 5, additional splits of the two OOAs were observed without providing either with more details on their sources or a better identification of the POAs.

The LV-OOA1 factor correlates better with eBC than the POA factor $\left(\mathrm{R}^{2}=0.80\right.$ for LV-OOA1 vs. eBC, while $\mathrm{R}^{2}=0.38$ for

110 POA vs. eBC). Since the LV-OOA1 is quite oxygenated $(\mathrm{O}: \mathrm{C}=0.91)$ and does not show a similar diurnal pattern to eBC $(\mathrm{Fig}$. SI-7 \& SI-8), it is quite difficult to link this factor to any local primary emission. Consequently, and due to its stability over the investigated factor solutions, it should be related to process anthropogenic and long-range transport of polluted air masses (see discussion in section 3.2.4 of the manuscript). Therefore, it clearly indicates the presence of two distinct sources of eBC: a local one related to the POA factor and a second one related to regional or transported aged primary emissions associated to

115 LV-OOA1 (details on the eBC source apportionment can be found in the dedicated section of the manuscript). 


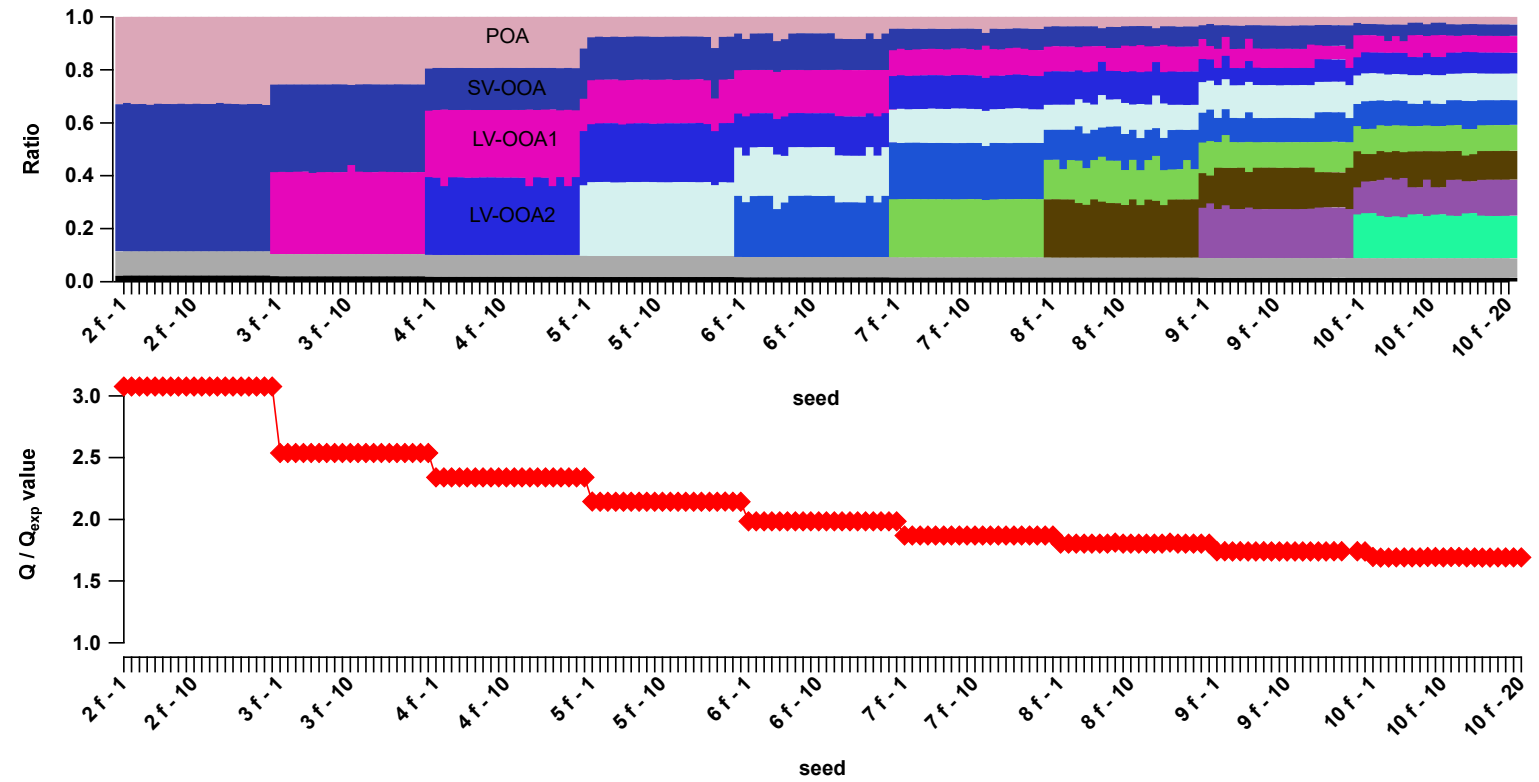

Figure SI-6: Variation of the factor contributions (top) and $Q / Q_{\exp }$ (bottom) over the investigated solution area for the unconstrained model. 

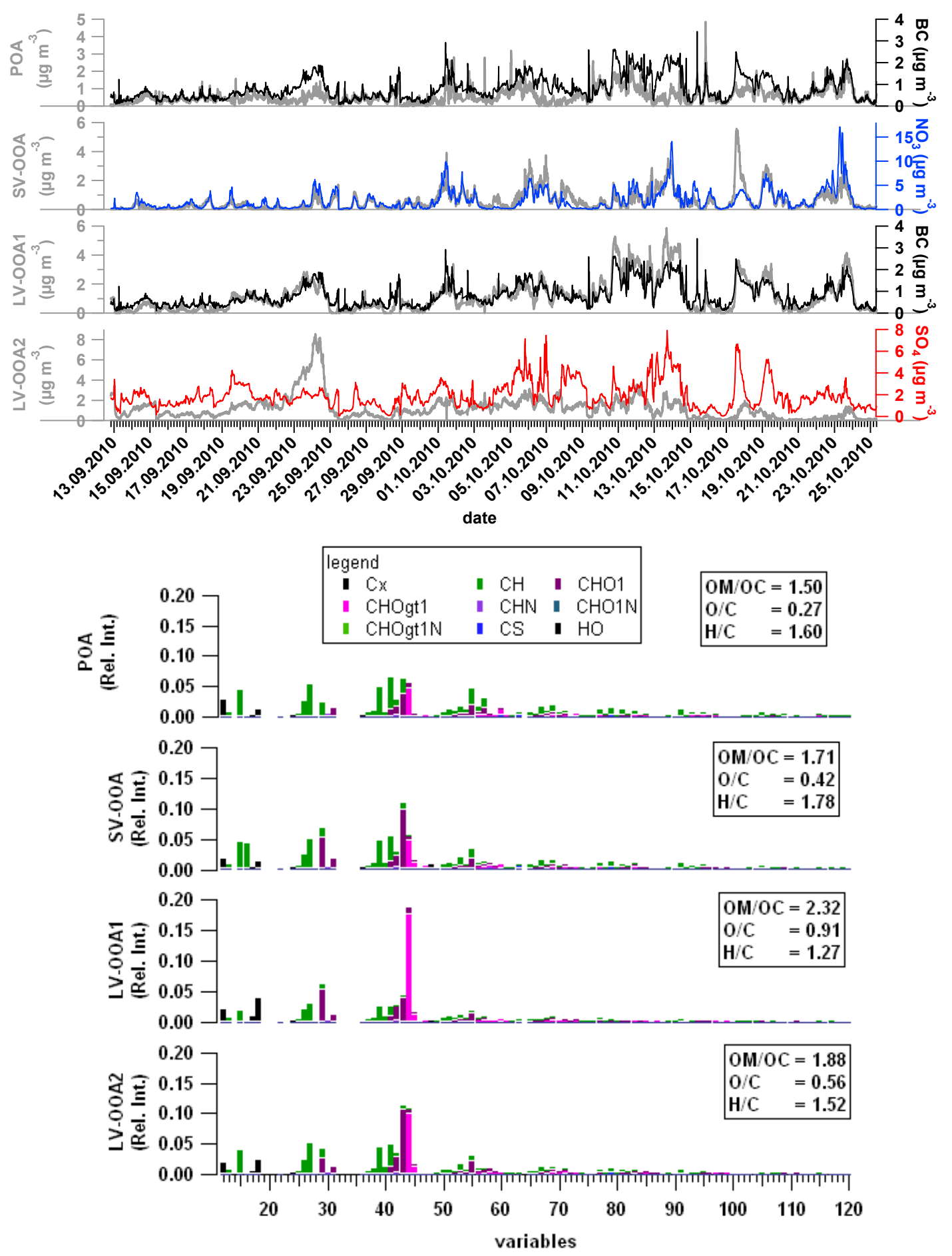

Figure SI-7: Time series of the PMF 4-factor solutions and comparison with collocated measurements (top). The corresponding highresolution mass spectra colored by fragment family codes is presented on the bottom. 

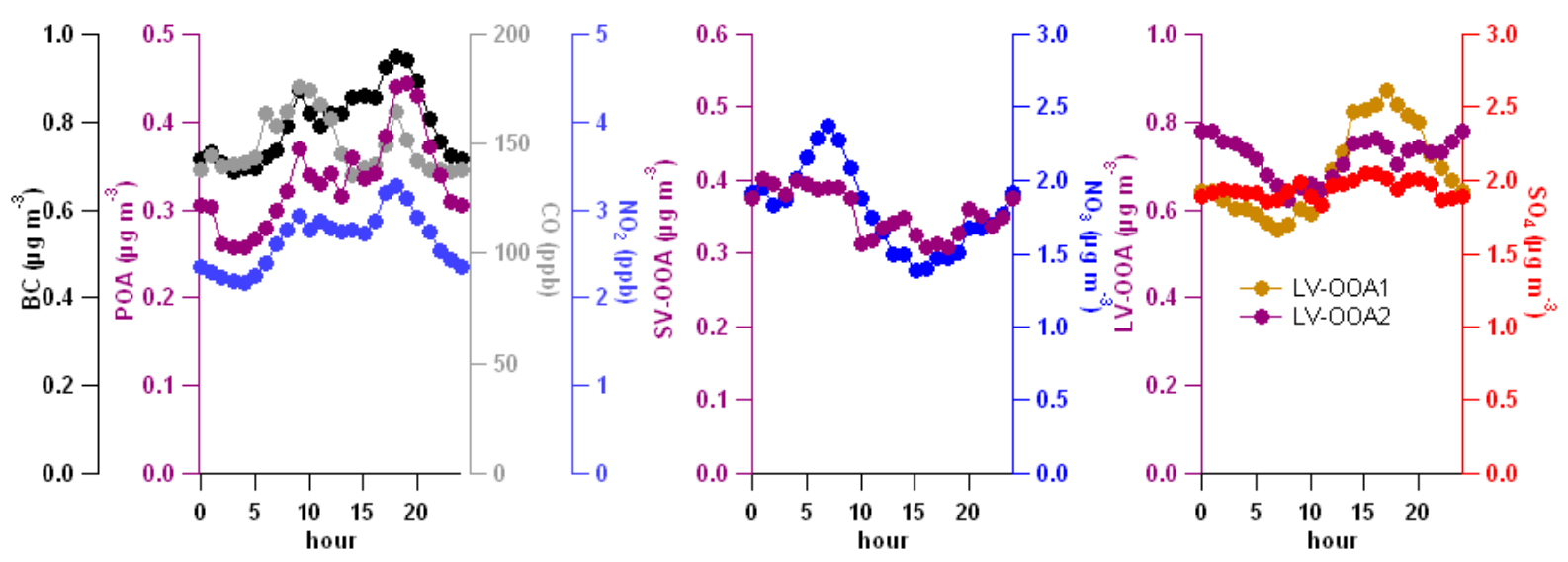

Figure SI-8: Diurnal pattern of the identify factors and collocated measurements for the non-constrained model. 

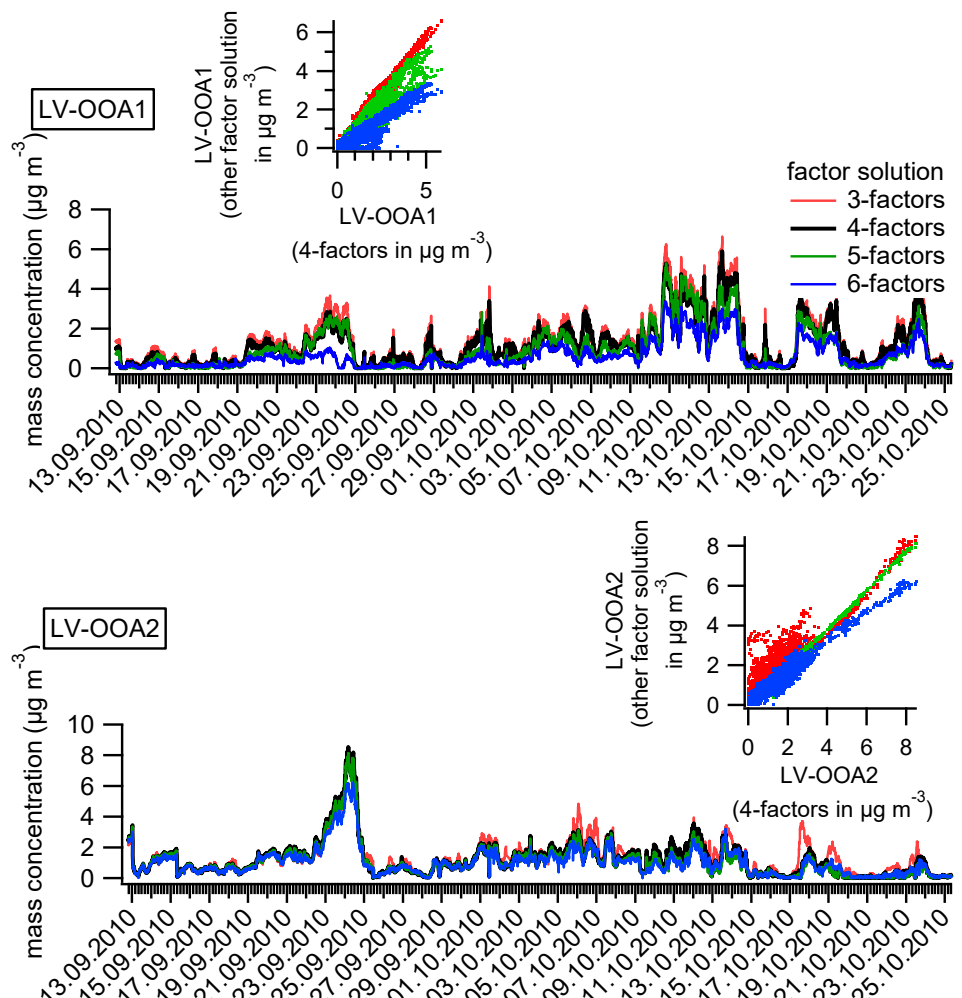

उ.

date and time
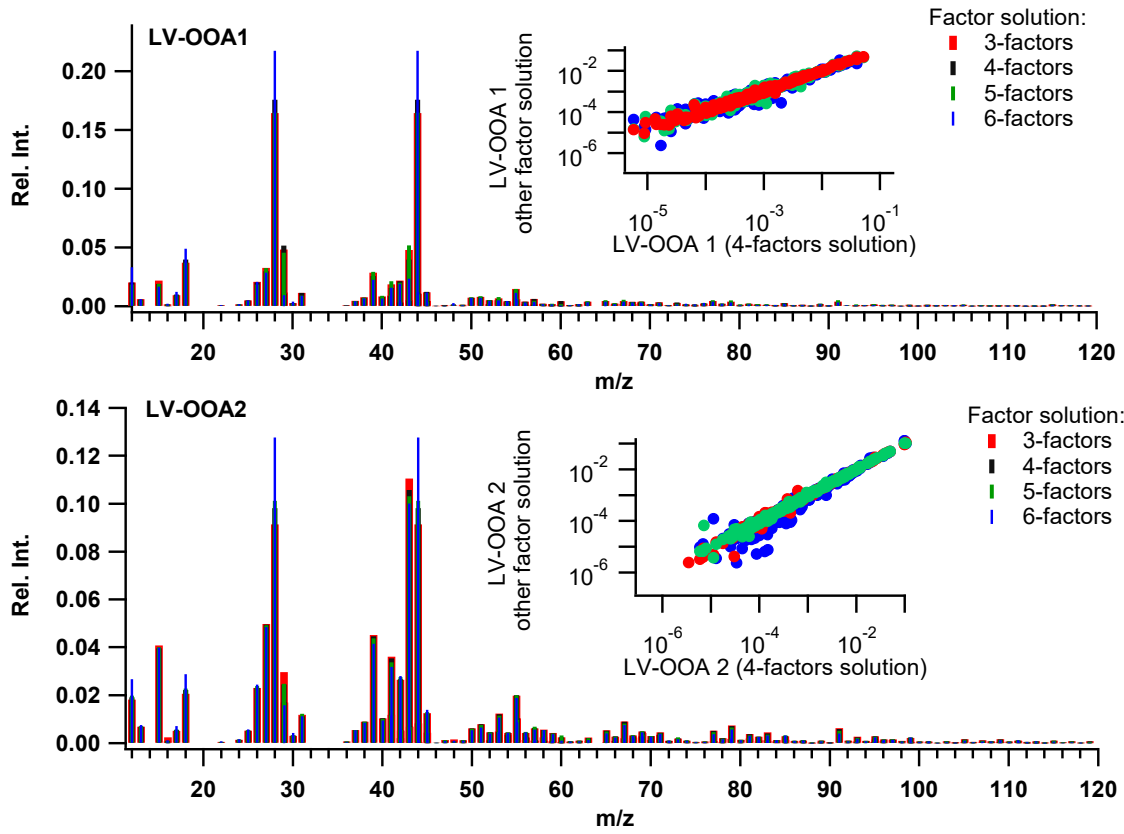

Figure SI-9: Comparison of the time series (top) and mass spectra (bottom in relative intensity) of the two LV-OOA factors ranging from 3- to 6-factor solutions. 


\section{SI-5-2-1 Constraining HOA}

Two different POA factors were expected based on the local emissions: an HOA factor related to traffic and fossil fuel combustion and biomass burning OA (BBOA). The presence of biomass burning OA is also confirmed when looking at the contribution of the fragment 60 to the total OA $\left(\mathrm{f}_{60}\right)$, which went above the threshold value of $0.3 \%$ suggested by Cubison et

140 al. (2011) (not shown). In order to better distinguish the different primary sources, the source apportionment model was therefore partly constrained, using as reference the HOA mass spectra from Mohr et al. (2012) obtained at Barcelona (Spain) and available on the reference mass spectra database (http://cires.colorado.edu/jimenez-group/HRAMSsd/, Ulbrich et al., 2009). Results were investigated using a factor number ranging from 2 to 9 with an anchor for the HOA factor ranging from 0.05 to 0.5 (Fig. SI-10 \& SI-11). Contribution of HOA to total OA was relatively stable over the entire investigated factor 145 solution as well as over the different a-values, as can be seen in Figure SI-11. Therefore, in the following, a solution with an a-value of 0.1 was considered. This corresponds to a quite constrained mass spectrum. From the 5 -factors solution a possible BBOA factor can be suspected based on the high contribution of $\mathrm{m} / \mathrm{z} 60$ and 73 . However, comparing the mass spectra of the 5-factor solutions BBOA with reference ones (Fig. SI-12) shows a very high contribution of $\mathrm{CO}_{2}^{+}$fragments, which might suggest a possible contribution of OOA and is therefore a non-properly resolved factor.

150 Additionally, the three OOAs (SV-OOA, LV-OOA1, and LV-OOA2) already identified in the non-constrained model were also found. The two LV-OOAs are extremely close to the ones identified in the non-constrained analysis (Fig. SI-11; LVOOA1: $\mathrm{R}^{2}=0.97$, slope 1.05 ; and $\mathrm{LV}-\mathrm{OOA} 2 \mathrm{R}^{2}=0.95$, slope 0.98 for their respective time series comparison). A larger discrepancy was observed for SV-OOA when comparing it to the non-constrained model $\left(\mathrm{R}^{2}=0.73\right.$, slope 0.67$)$. This could result from a possible contribution of the BBOA factor to the non-constrained SV-OOA factor, confirming the non-ideal apportionment of the BBOA factor.

Increasing the number of factors leads mainly to an additional split of the OOAs. Interestingly, a well-defined BBOA mass spectrum was found for the 9-factors solution. This BBOA factor is in agreement with the reference mass spectra proposed by $\mathrm{Ng}$ et al. (2011), as well as with the averaged BBOA factor obtained during the EUCAARI project in Europe Crippa et al. (2014) (Fig. SI-12). Consequently, a third model was built, constraining the HOA mass spectra as previously, as well as a

160 BBOA factor using the identified BBOA mass spectra on the 9-factors solution. Since the BBOA directly results from the present dataset, the BBOA mass spectrum was constrained with a fixed a-value of 0.1. 


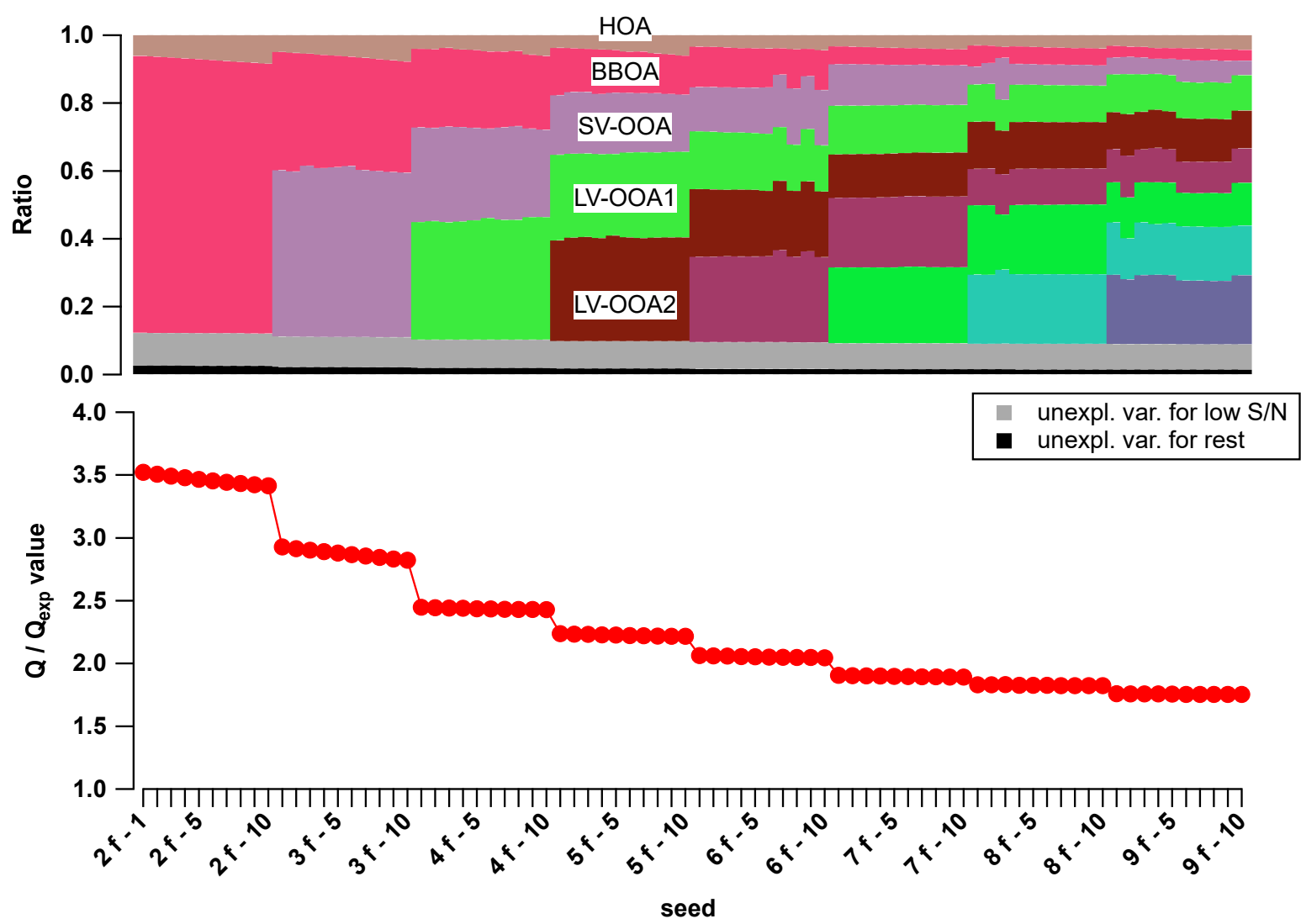

165 Figure SI-10: Variation of the $\mathbf{Q} / \mathbf{Q}_{\exp }($ top) and factor contributions (bottom) over the investigated solution area with constrained HOA. 

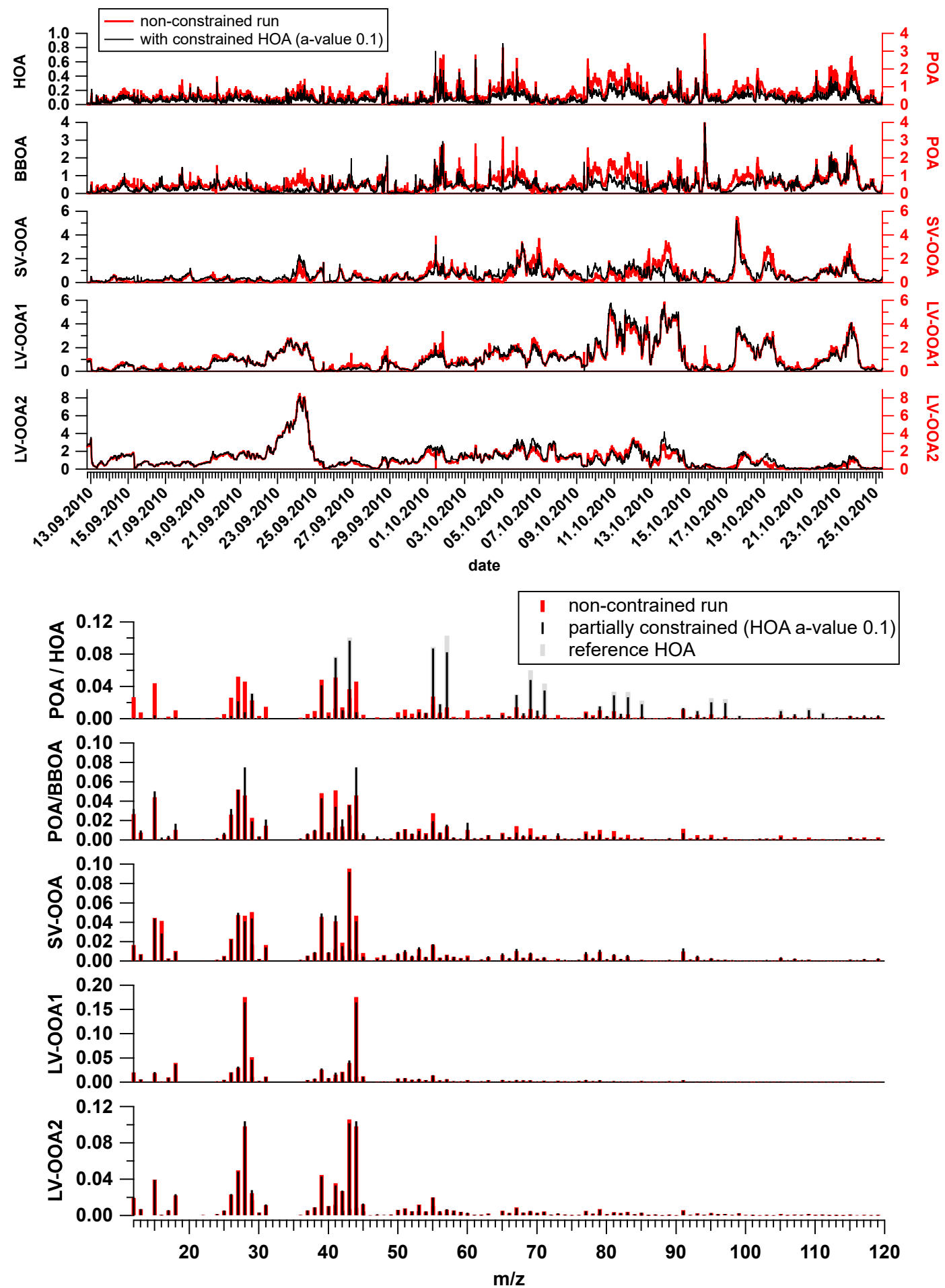

170 Figure SI-11: Comparison of the time series (top, in $\mu \mathrm{g}^{-3}$ ) and mass spectra (bottom) of the 5-factors solution partly-constrained approach (fixed HOA with a-value $=0.1$ ) and the non-constrained one (red). 


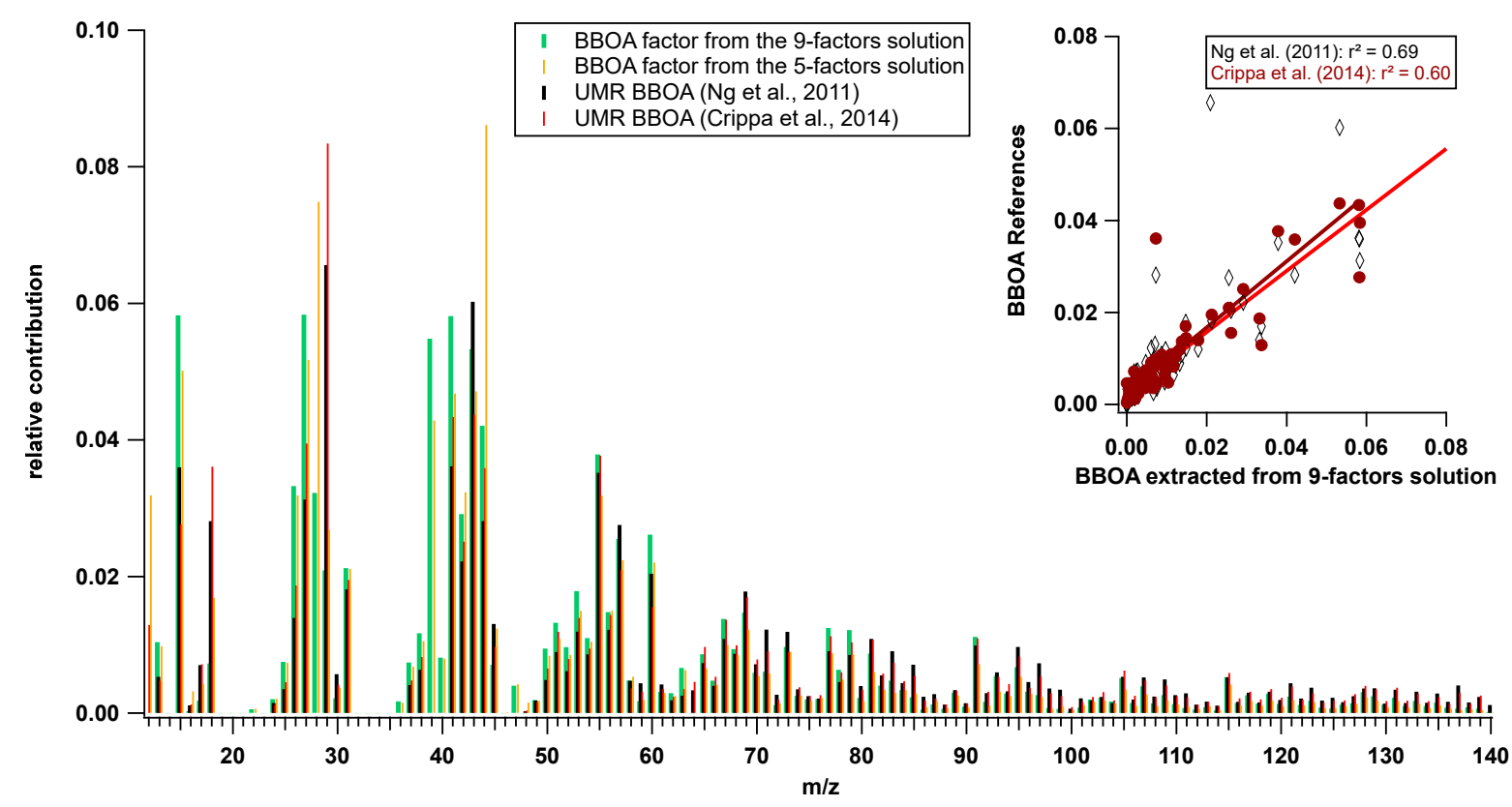

Figure SI-12: Comparison of the identified BBOA factor for the 9-factors solution with reference mass spectra from Ng et al. (2011) and Crippa et al. (2014). The insert panel represents the scatter plots between the identified BBOA factor (after averaging to unit mass resolution (UMR)) and the 2 references.

\section{SI-5-2-2 Constraining HOA and BBOA}

The investigation of the third model run is presented in Figure SI-13. Here, the 5-factors solution was retained as a final source apportionment result, which corresponds to the identification of the expected two primary OA (HOA and BBOA) and three additional OOA factors (SV-OOA, LO-OOA, and MO-OOA) (Fig. 5 on the manuscript). Both mass spectra and time series of the three OOA factors identified in this third model are similar to the ones obtained in the non-constrained model (Fig. SI-14 $\& 15)$. This confirmed the robustness of the OOAs identification, as well as the correct speciation of the POA factor identity on the non-constrained model. The larger variation in the elemental composition was found for the SV-OOA factor, which could be related to a small contribution from BBOA on the non-constrained results, as was mentioned before. The identification of the BBOA factor is confirmed by the comparison of the factor mass concentrations with the levoglucosan concentrations obtained from the off-line filter measurements made during IOPs (Fig. SI-16). 


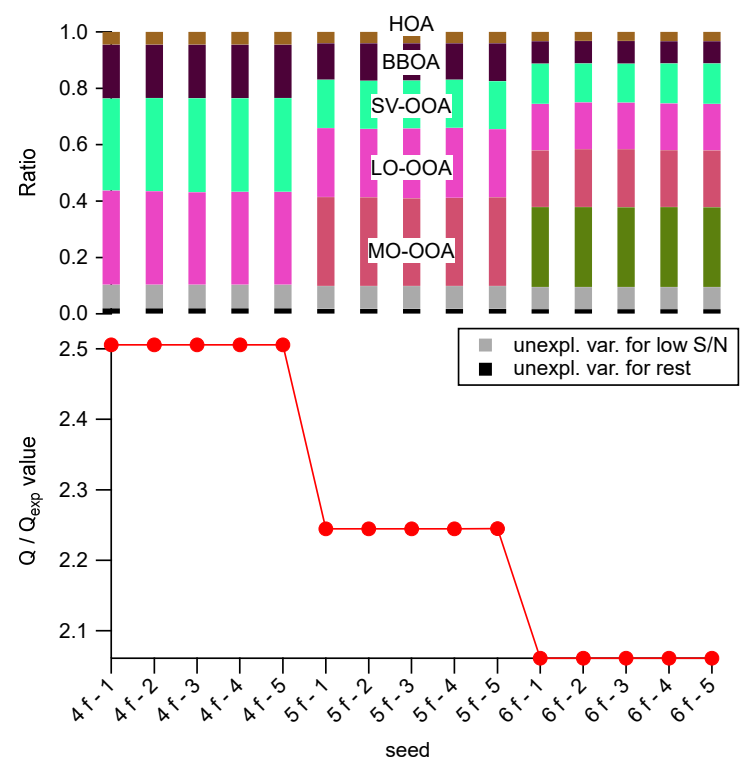

190 Figure SI-13: Variation of the Q/Qexp (top) and factor contributions (bottom) over the investigated solution area with constrained HOA and BBOA. 


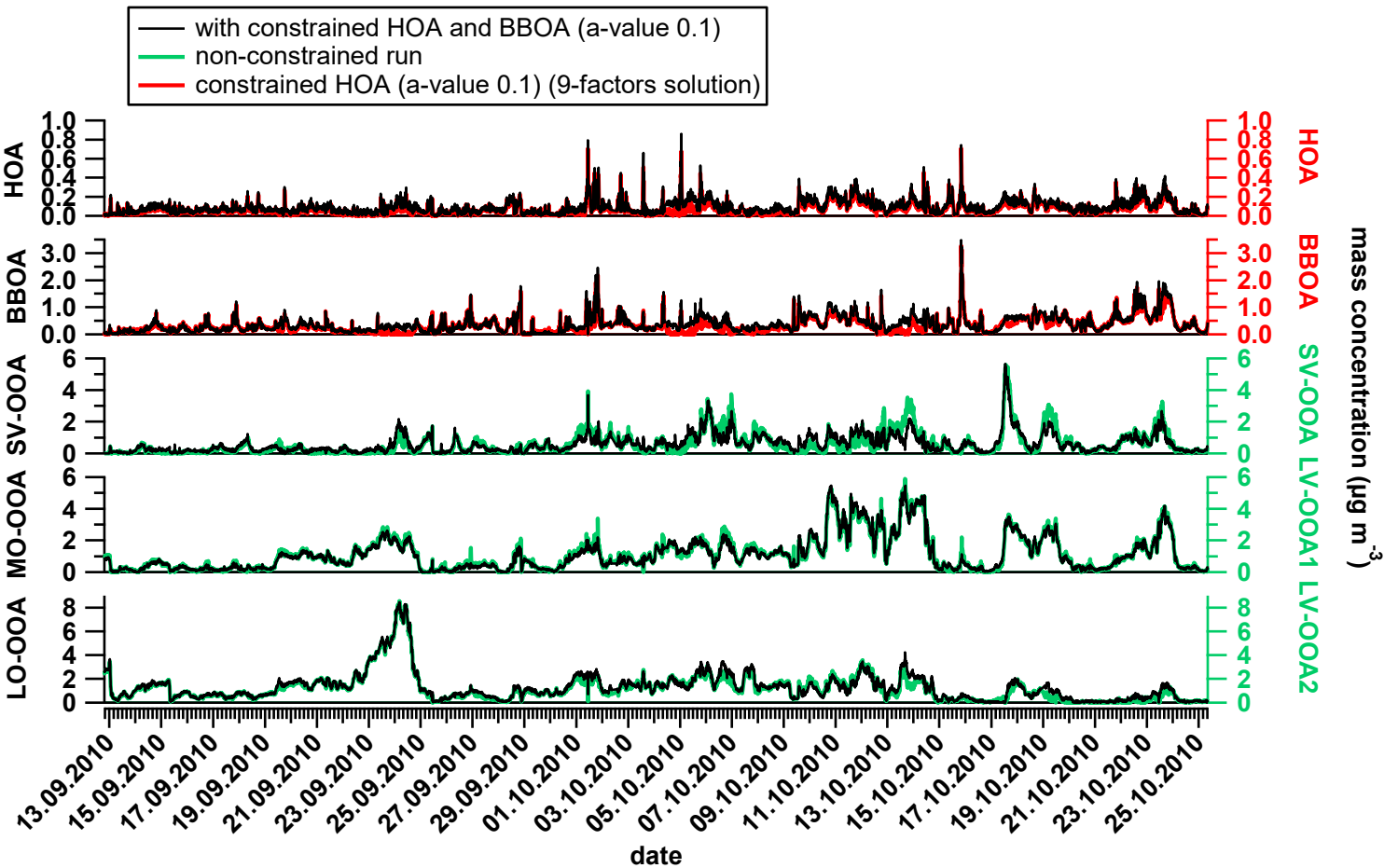

Figure SI-14: Comparison of 5-factors solution time series with constrained HOA and BBOA (left axis) with the previously identified ones (right axis) obtained during the 9-factors solution (with fixed HOA) for HOA and BBOA (red) and the PMF results (nonconstrained) for the two OOAs (green). 

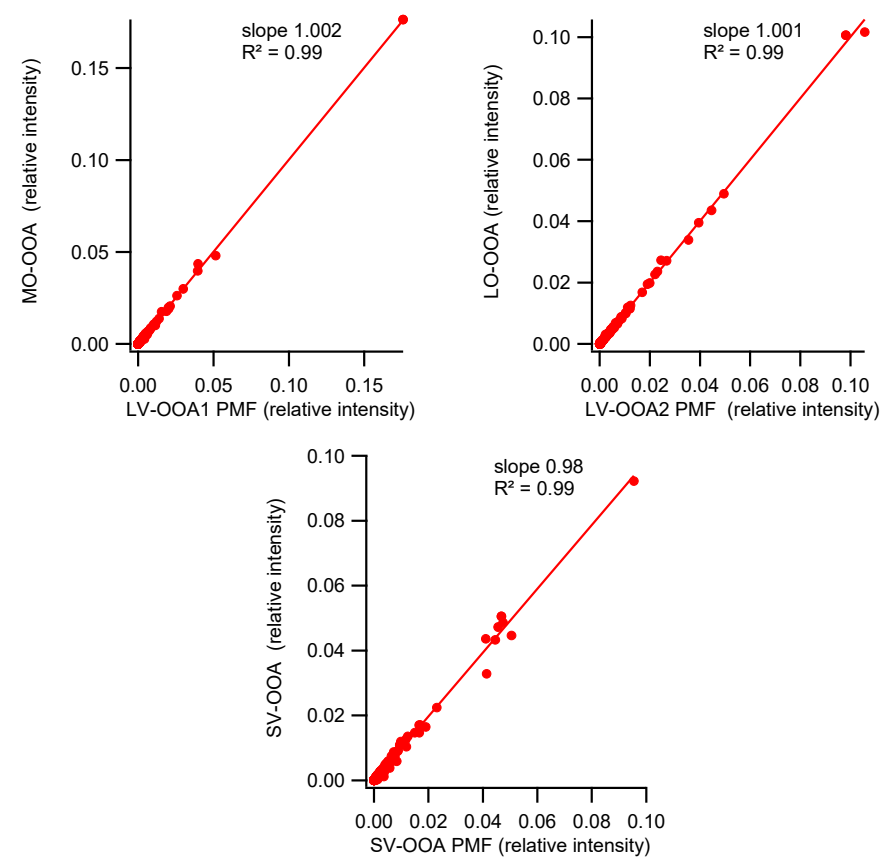

200 Figure SI-15: Comparison of the OOAs mass spectra from the final HOA and BBOA constrained factor solutions with the ones previously obtained on the non-constrained solution. 

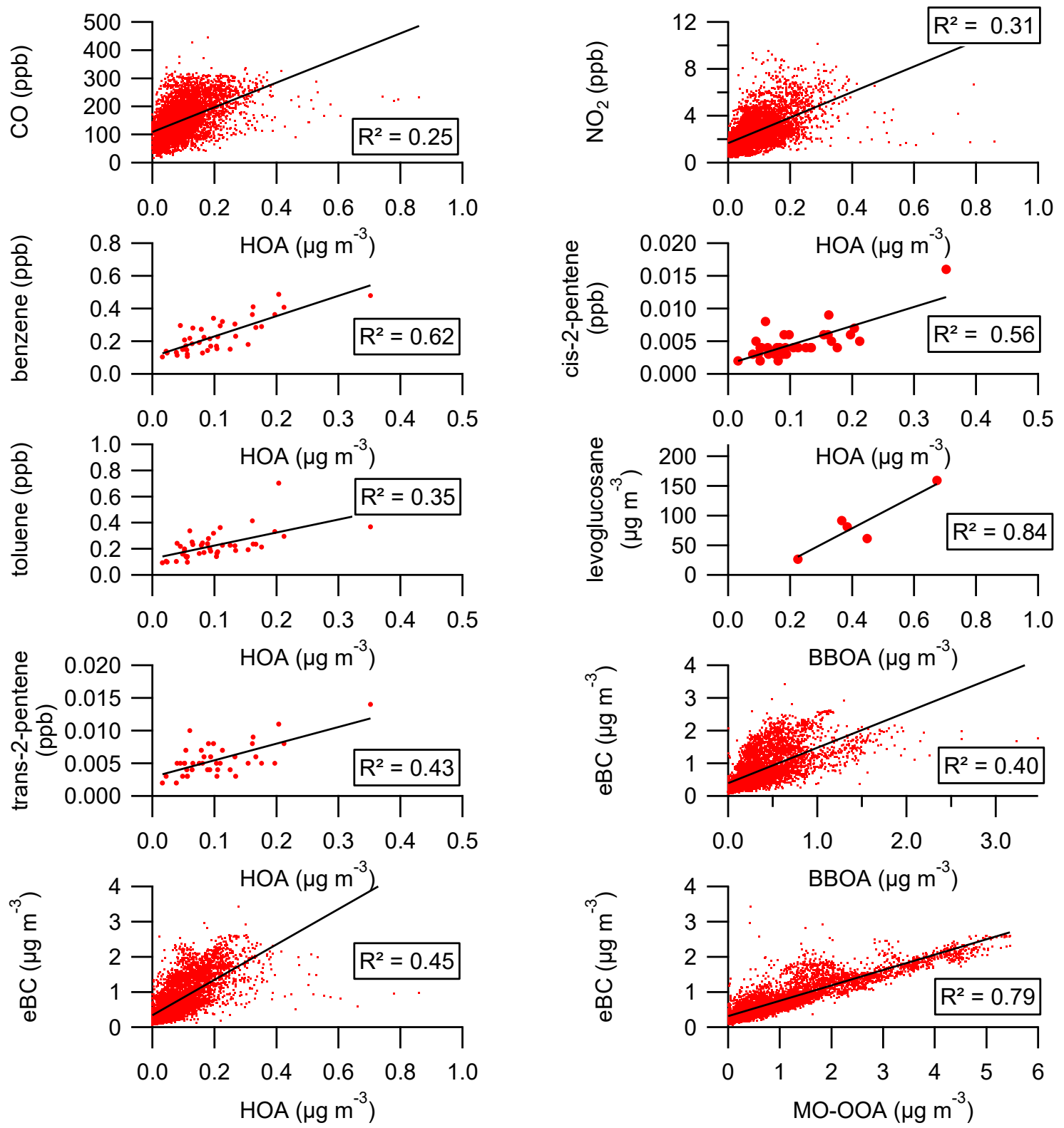

Figure SI-16: Scatter plot of the identified factors (HOA, BBOA, and MO-OOA) vs. their corresponding tracers during intensive sampling periods. The correlation curves (red lines) were calculated using the least orthogonal distance fit method. 

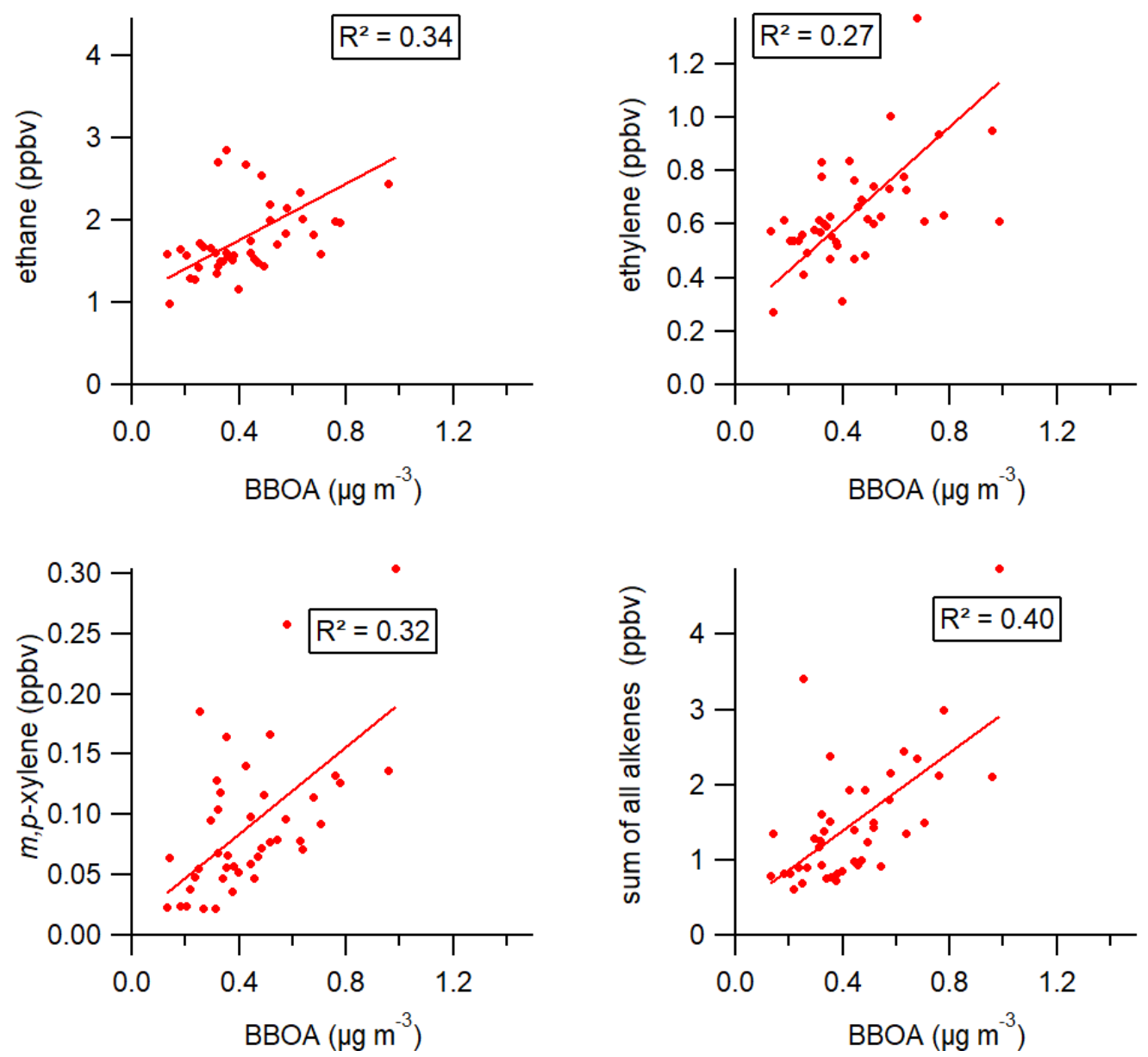

Figure SI-16: Continued 

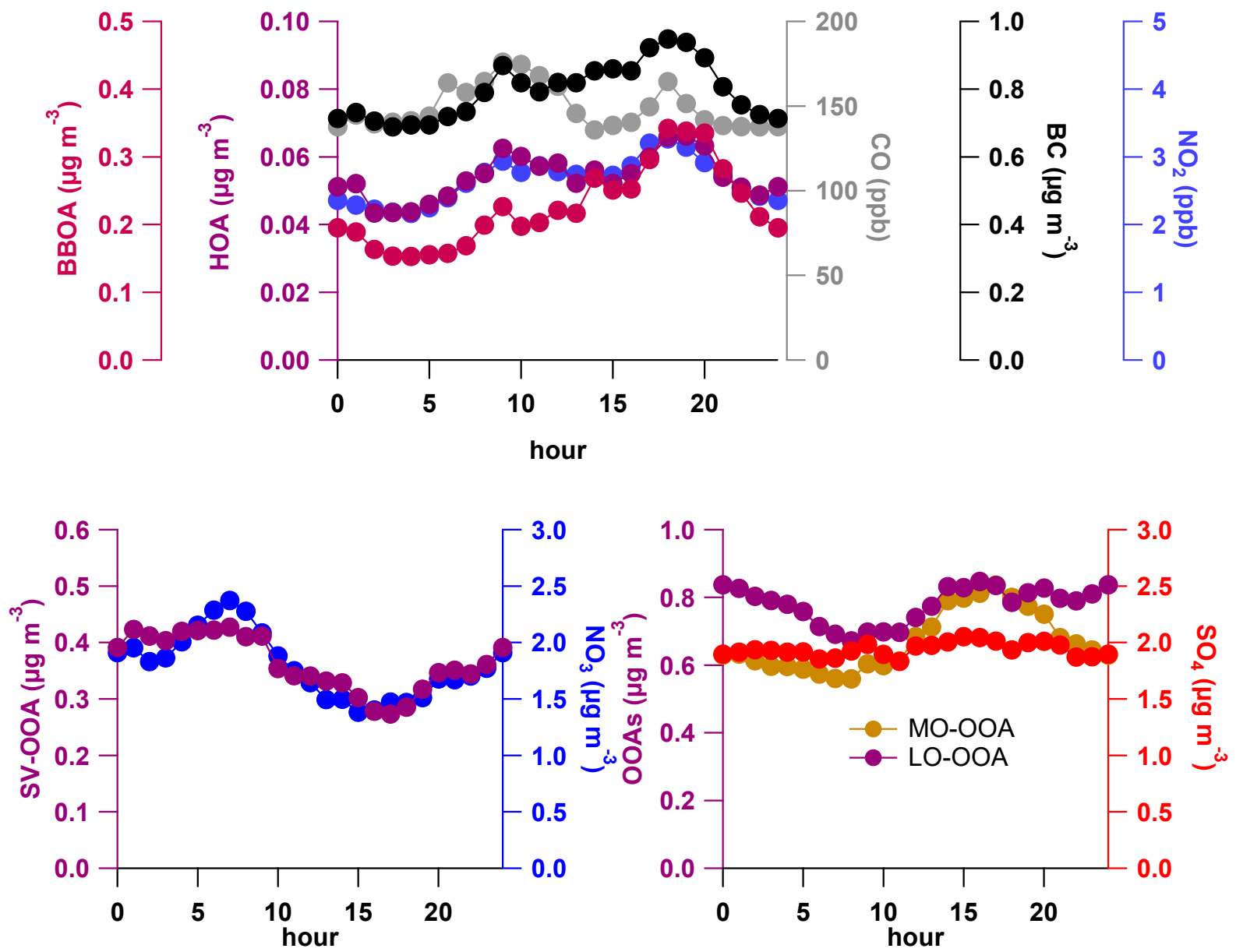

210 Figure SI-17: Diurnal profiles of the 5-factors solutions and their corresponding tracers. 

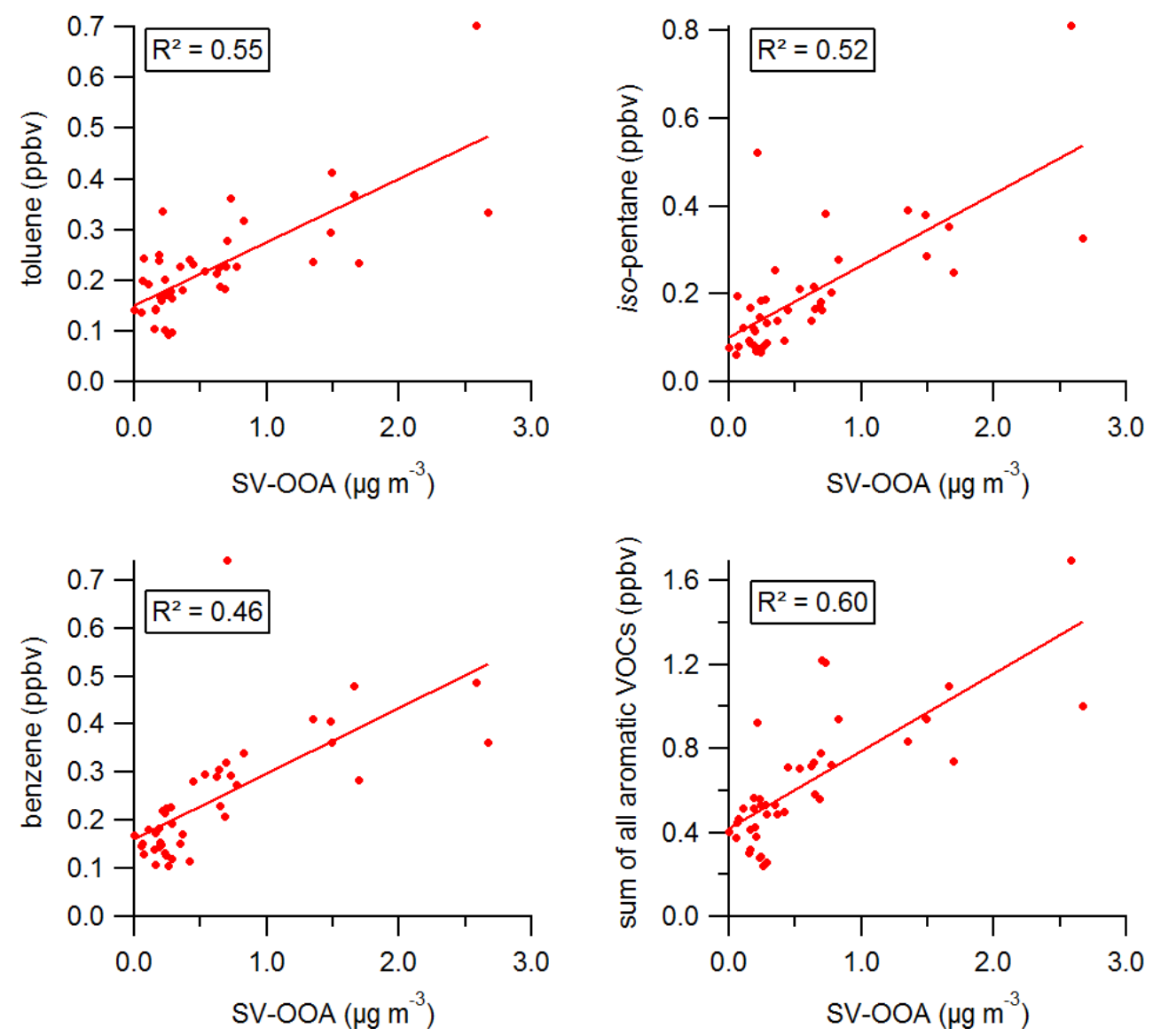

Figure SI-18: Scatter plot of the SV-OOA vs. anthropogenic NMHC gases. The correlation curves (red lines) were calculated using the least orthogonal distance fit method. 


\section{SI-6: Overview of the NMHC measurements}

Table SI-3: Overview of the average gas-phase concentrations NMHC (in ppbv \pm standard deviation) during full-cloud events (FCE) and non-cloud events (NCE).

\begin{tabular}{|c|c|c|c|c|c|c|c|c|c|c|c|}
\hline & $\begin{array}{c}\mathrm{FCE} \\
1.1 \\
\end{array}$ & $\begin{array}{c}\text { NCE } \\
0.1 \\
\end{array}$ & $\begin{array}{c}\text { NCE } \\
0.2 \\
\end{array}$ & $\begin{array}{l}\text { FCE } \\
11.2 \\
\end{array}$ & $\begin{array}{l}\text { FCE } \\
11.3 \\
\end{array}$ & $\begin{array}{l}\text { FCE } \\
12.1 \\
\end{array}$ & $\begin{array}{l}\text { FCE } \\
13.1 \\
\end{array}$ & $\begin{array}{l}\text { FCE } \\
13.3 \\
\end{array}$ & $\begin{array}{l}\text { FCE } \\
22.1 \\
\end{array}$ & $\begin{array}{c}\text { NCE } \\
0.3 \\
\end{array}$ & $\begin{array}{c}\text { FCE } \\
26 \\
\end{array}$ \\
\hline Starting time & $\begin{array}{c}14.09 . \\
2010 \\
12: 44\end{array}$ & $\begin{array}{c}15.09 . \\
2010 \\
18: 00\end{array}$ & $\begin{array}{c}20.09 . \\
2010 \\
11: 25\end{array}$ & $\begin{array}{c}01.10 .2 \\
010 \\
22: 33\end{array}$ & $\begin{array}{c}02.10 . \\
2010 \\
14: 33\end{array}$ & $\begin{array}{c}05.10 . \\
2010 \\
08: 30\end{array}$ & $\begin{array}{c}05.10 . \\
2010 \\
19: 15\end{array}$ & $\begin{array}{c}06.10 . \\
2010 \\
12: 15\end{array}$ & $\begin{array}{c}19.10 . \\
2010 \\
21: 30\end{array}$ & $\begin{array}{c}21.10 . \\
2010 \\
14: 15\end{array}$ & $\begin{array}{c}24.10 . \\
2010 \\
01: 30\end{array}$ \\
\hline Stopping time & $\begin{array}{c}15.09 . \\
2010 \\
00: 00\end{array}$ & $\begin{array}{c}15.09 . \\
2010 \\
23: 30 \\
\end{array}$ & $\begin{array}{c}20.09 . \\
2010 \\
20: 30 \\
\end{array}$ & $\begin{array}{c}02.10 \\
2010 \\
05: 30\end{array}$ & $\begin{array}{c}02.10 . \\
2010 \\
20: 00 \\
\end{array}$ & $\begin{array}{c}05.10 . \\
2010 \\
13: 00 \\
\end{array}$ & $\begin{array}{c}06.10 . \\
2010 \\
04: 30 \\
\end{array}$ & $\begin{array}{c}07.10 . \\
2010 \\
02: 45 \\
\end{array}$ & $\begin{array}{c}20.10 . \\
2010 \\
03: 30\end{array}$ & $\begin{array}{c}21.10 . \\
2010 \\
22: 15 \\
\end{array}$ & $\begin{array}{c}24.10 . \\
2010 \\
11: 45 \\
\end{array}$ \\
\hline Cluster & $\mathrm{C} 1$ & $\mathrm{C} 1$ & $\mathrm{C} 1$ & $\mathrm{C} 3$ & $\mathrm{C} 3$ & $\begin{array}{l}\text { C4 to } \\
\text { C3 }\end{array}$ & $\mathrm{C} 3$ & $\begin{array}{c}\text { C3 to } \\
\text { C4 }\end{array}$ & $\mathrm{C} 1$ & $\mathrm{C} 1$ & $\begin{array}{c}\mathrm{C} 3 \text { to } \\
\mathrm{C} 2 \text { via } \\
\mathrm{C} 1\end{array}$ \\
\hline & \multicolumn{11}{|c|}{ NMHC } \\
\hline $\mathrm{Nb}$ of samples & 5 & 3 & 6 & 4 & 3 & 2 & 5 & 0 & 3 & 3 & 6 \\
\hline Acetylene & $\begin{array}{c}0.61 \pm \\
0.16\end{array}$ & $\begin{array}{c}0.46 \pm \\
0.13\end{array}$ & $\begin{array}{c}0.62 \pm \\
0.09\end{array}$ & $\begin{array}{c}0.60 \pm \\
0.03\end{array}$ & $\begin{array}{c}0.87 \pm \\
0.44\end{array}$ & $\begin{array}{c}0.81 \pm \\
0.04\end{array}$ & $\begin{array}{c}0.82 \pm \\
0.15\end{array}$ & \multirow{8}{*}{ No data } & $\begin{array}{c}0.71 \pm \\
0.23\end{array}$ & $\begin{array}{c}0.60 \pm 0 . \\
13\end{array}$ & $\begin{array}{c}0.55 \pm \\
0.06\end{array}$ \\
\hline Alkenes & $\begin{array}{c}1.35 \pm \\
1.15\end{array}$ & $\begin{array}{c}0.79 \pm \\
0.16\end{array}$ & $\begin{array}{c}0.86 \pm \\
0.11\end{array}$ & $\begin{array}{c}1.36 \pm \\
0.12\end{array}$ & $\begin{array}{c}1.70 \pm \\
0.58\end{array}$ & $\begin{array}{c}1.77 \pm \\
0.23\end{array}$ & $\begin{array}{c}2.24 \pm \\
0.54\end{array}$ & & $\begin{array}{c}1.78 \pm \\
0.37\end{array}$ & $\begin{array}{c}1.72 \pm 0 . \\
57\end{array}$ & $\begin{array}{c}1.07 \pm \\
0.44\end{array}$ \\
\hline Aromatics & $\begin{array}{c}0.60 \pm \\
0.18\end{array}$ & $\begin{array}{c}0.41 \pm \\
0.08\end{array}$ & $\begin{array}{c}0.44 \pm \\
0.08\end{array}$ & $\begin{array}{c}0.78 \pm \\
0.11\end{array}$ & $\begin{array}{c}0.88 \pm \\
0.29\end{array}$ & $\begin{array}{c}0.89 \pm \\
0.08\end{array}$ & $\begin{array}{c}1.09 \pm \\
0.39\end{array}$ & & $\begin{array}{c}0.64 \pm \\
0.12\end{array}$ & $\begin{array}{c}0.49 \pm \\
0.07\end{array}$ & $\begin{array}{c}0.31 \pm \\
0.09\end{array}$ \\
\hline$n$-alkanes & $\begin{array}{c}3.36 \pm \\
1.45\end{array}$ & $\begin{array}{c}2.33 \pm \\
0.66\end{array}$ & $\begin{array}{c}2.64 \pm \\
0.24\end{array}$ & $\begin{array}{c}3.35 \pm \\
0.34\end{array}$ & $\begin{array}{c}2.97 \pm \\
0.29\end{array}$ & $\begin{array}{c}6.06 \pm \\
0.28\end{array}$ & $\begin{array}{c}5.02 \pm \\
0.36\end{array}$ & & $\begin{array}{c}3.35 \pm \\
0.27\end{array}$ & $\begin{array}{c}4.15 \pm \\
0.37\end{array}$ & $\begin{array}{c}2.96 \pm \\
0.87\end{array}$ \\
\hline i-alkanes & $\begin{array}{c}0.66 \pm \\
0.52\end{array}$ & $\begin{array}{c}0.43 \pm \\
0.19\end{array}$ & $\begin{array}{c}0.36 \pm \\
0.06\end{array}$ & $\begin{array}{c}0.67 \pm \\
0.07\end{array}$ & $\begin{array}{c}0.49 \pm \\
0.03\end{array}$ & $\begin{array}{l}1.31 \pm \\
0.09\end{array}$ & $\begin{array}{c}1.09 \pm \\
0.38\end{array}$ & & $\begin{array}{c}0.61 \pm \\
0.07\end{array}$ & $\begin{array}{c}0.67 \pm \\
0.06\end{array}$ & $\begin{array}{c}0.37 \pm \\
0.11\end{array}$ \\
\hline Total NMHC & $\begin{array}{c}6.59 \pm \\
3.17\end{array}$ & $\begin{array}{c}4.42 \pm \\
1.03\end{array}$ & $\begin{array}{c}4.91 \pm \\
0.50\end{array}$ & $\begin{array}{c}6.74 \pm \\
0.59\end{array}$ & $\begin{array}{c}6.90 \pm \\
1.58\end{array}$ & $\begin{array}{c}10.82 \pm \\
0.72\end{array}$ & $\begin{array}{c}10.25 \pm \\
1.21\end{array}$ & & $\begin{array}{c}7.08 \pm \\
0.92\end{array}$ & $\begin{array}{l}7.63 \pm \\
0.81\end{array}$ & $\begin{array}{c}5.26 \pm \\
1.43\end{array}$ \\
\hline $\begin{array}{l}\text { Benzene-to- } \\
\text { toluene ratio }\end{array}$ & 0.83 & 0.68 & 0.97 & 1.25 & 1.74 & 1.56 & 1.03 & & 1.26 & 1.26 & 1.20 \\
\hline $\begin{array}{c}\text { Xylene-to-toluene } \\
\text { ratio }\end{array}$ & 0.58 & 0.35 & 0.47 & 0.74 & 0.70 & 0.64 & 0.58 & & 0.74 & 0.57 & 0.42 \\
\hline
\end{tabular}


SI-7 Influence of air mass origin on local aerosol and gas composition

230 Table SI-4: Gas phase tracer and particle mean composition for the different air mass clusters (all concentrations in $\mu \mathrm{g} \mathbf{m}^{-3}$ )

\begin{tabular}{|c|c|c|c|c|c|c|}
\hline cluster (hours) & C1 (307) & $\mathrm{C} 2(165)$ & C3 (179) & C4 (84) & C5 (88) & C6 (173) \\
\hline region of air mass origin & West & Northwest & Southwest & South & Northeast & East \\
\hline \multicolumn{7}{|c|}{ Gas-phase measurements } \\
\hline $\mathrm{HCl}$ mean (median) in $\mu \mathrm{g} \mathrm{m}^{-3}$ & $0.15(0.11)$ & $0.09(0.09)$ & $0.29(0.21)$ & $0.36(0.37)$ & $0.21(0.21)$ & $0.13(0.14)$ \\
\hline Min. /Max. & $0.05 / 0.65$ & $0.06 / 0.15$ & $0.05 / 0.75$ & $0.07 / 0.62$ & $0.21 / 0.21$ & $0.06 / 0.30$ \\
\hline HONO mean (median) in $\mu \mathrm{g} \mathrm{m}^{-3}$ & $0.76(0.74)$ & $0.72(0.67)$ & $0.67(0.62)$ & $0.78(0.76)$ & $0.38(0.39)$ & $0.43(0.32)$ \\
\hline Min. /Max. & $0.11 / 2.44$ & $0.10 / 2.42$ & $0.17 / 1.81$ & $0.16 / 1.39$ & $0.08 / 0.92$ & $0.08 / 1.64$ \\
\hline $\mathrm{SO}_{2}$ mean (median) in $\mu \mathrm{g} \mathrm{m}^{-3}$ & $0.32(0.24)$ & $0.30(0.25)$ & $0.40(0.26)$ & $0.37(0.25)$ & $0.66(0.21)$ & $2.48(1.49)$ \\
\hline Min. /Max. & $0.10 / 1.46$ & $0.10 / 0.68$ & $0.1 / 2.00$ & $0.11 / 1.71$ & $0.10 / 3.50$ & $0.14 / 13.27$ \\
\hline $\mathrm{HNO}_{3}$ mean (median) in $\mu \mathrm{g} \mathrm{m}^{-3}$ & $0.16(0.13)$ & $0.14(0.12)$ & $0.32(0.23)$ & $0.25(0.18)$ & $0.17(0.11)$ & $0.34(0.30)$ \\
\hline Min. /Max. & $0.05 / 1.04$ & $0.05 / 0.83$ & $0.06 / 5.77$ & $0.05 / 1.21$ & $0.05 / 0.53$ & $0.05 / 1.15$ \\
\hline Ozone mean (median) in ppb & $42.69(41.39)$ & $38.40(40.27)$ & $39.96(35.37)$ & $38.46(33.13)$ & $42.77(40.50)$ & $57.01(60.01)$ \\
\hline Min. /Max. & $8.73 / 81.09$ & $7.86 / 71.6$ & $7.77 / 94.78$ & $8.28 / 99.75$ & $14.92 / 81.13$ & $8.01 / 90.73$ \\
\hline NO mean (median) in ppb & $0.42(0.15)$ & $0.32(0.12)$ & $0.52(0.28)$ & $0.95(0.19)$ & $0.35(0.21)$ & $0.71(0.42)$ \\
\hline Min. /Max. & $0.01 / 5.88$ & $0.01 / 4.51$ & $0.01 / 8.08$ & $0.01 / 7.78$ & $0.01 / 1.47$ & $0.01 / 4.88$ \\
\hline $\mathrm{NO}_{2}$ mean (median) in $\mathrm{ppb}$ & $5.17(4.57)$ & $4.51(4.19)$ & $5.87(5.63)$ & $4.75(4.64)$ & $4.53(4.65)$ & $5.60(5.21)$ \\
\hline Min. /Max. & $0.96 / 16.04$ & $1.04 / 13.19$ & $1.86 / 13.79$ & $1.76 / 10.17$ & $1.05 / 11.07$ & $1.88 / 15.22$ \\
\hline
\end{tabular}


Table SI-4: Continued

\begin{tabular}{|c|c|c|c|c|c|c|}
\hline cluster (hours) & C1 (307) & $\mathrm{C} 2(165)$ & C3 (179) & C4 (84) & C5 (88) & C6 (173) \\
\hline region of air mass origin & West & Northwest & Southwest & South & Northeast & East \\
\hline \multicolumn{7}{|c|}{ Aerosol measurements in $\mu \mathrm{g} \mathrm{m}^{-3}$} \\
\hline $\begin{array}{c}\text { Total mass concentration } \\
\text { mean (median) }\end{array}$ & $7.54(7.61)$ & $6.38(5.83)$ & $11.50(9.93)$ & $11.38(10.78)$ & $7.97(5.75)$ & $12.65(11.40)$ \\
\hline Min. / Max. & $0.23 / 18.70$ & $1.07 / 20.28$ & $4.23 / 23.22$ & $4.08 / 21.33$ & $1.13 / 27.47$ & $0.73 / 29.66$ \\
\hline Organic (AMS) mean (median) & $2.07(1.90)$ & $1.86(1.57)$ & $4.99(4.44)$ & $5.39(5.05)$ & $3.18(2.12)$ & $5.76(5.66)$ \\
\hline Min. /Max. & $0.18 / 5.06$ & $0.28 / 6.62$ & $1.52 / 12.0$ & $2.30 / 11.36$ & $0.30 / 9.73$ & $1.19 / 10.55$ \\
\hline eBC (MAAP) mean (median) & $0.52(0.49)$ & $0.50(0.41)$ & $1.03(0.91)$ & $1.01(0.93)$ & $0.74(0.41)$ & $1.31(1.32)$ \\
\hline Min /Max. & $0.08 / 1.5$ & $0.10 / 1.83$ & $0.31 / 2.22$ & $0.56 / 3.07$ & $0.11 / 2.31$ & $0.16 / 3.2$ \\
\hline Chloride (MARGA) mean (median) & $0.29(0.21)$ & $0.27(0.23)$ & $0.11(0.10)$ & $0.08(0.08)$ & $0.14(0.12)$ & $0.21(0.22)$ \\
\hline Min. /Max. & $0.05 / 1.45$ & $0.05 / 0.78$ & $0.05 / 0.25$ & $0.05 / 0.10$ & $0.06 / 0.27$ & $0.05 / 0.33$ \\
\hline Nitrate (MARGA) mean (median) & $1.87(1.67)$ & $1.55(1.20)$ & $2.33(1.92)$ & $1.64(1.32)$ & $1.40(0.88)$ & $2.25(1.90)$ \\
\hline Min. /Max. & $0.14 / 8.99$ & $0.29 / 6.56$ & $0.20 / 8.91$ & $0.14 / 4.68$ & $0.11 / 7.40$ & $0.17 / 9.90$ \\
\hline Sulfate (MARGA) mean (median) & $1.12(1.11)$ & $1.04(0.96)$ & $1.39(1.12)$ & $1.96(1.75)$ & $1.36(1.04)$ & $1.83(1.76)$ \\
\hline Min. /Max. & $0.09 / 2.49$ & $0.14 / 3.34$ & $0.46 / 4.41$ & $0.29 / 4.29$ & $0.10 / 4.49$ & $0.55 / 4.45$ \\
\hline Ammonium (MARGA) mean (median) & $0.83(0.74)$ & $0.74(0.59)$ & $1.23(1.10)$ & $1.28(1.14)$ & $0.94(0.61)$ & $1.38(1.12)$ \\
\hline Min. /Max. & $0.08 / 3.18$ & $0.11 / 2.96$ & $0.29 / 3.58$ & $0.21 / 3.14$ & $0.10 / 4.06$ & $0.25 / 4.53$ \\
\hline Potassium (MARGA) mean (median) & $0.14(0.13)$ & $0.12(0.11)$ & $0.13(0.12)$ & $0.14(0.14)$ & $0.12(0.12)$ & $0.13(0.12)$ \\
\hline Min. /Max. & $0.1 / 0.26$ & $0.10 / 0.18$ & $0.10 / 0.20$ & $0.11 / 0.22$ & $0.10 / 0.18$ & $0.10 / 0.20$ \\
\hline Sodium (MARGA) mean (median) & $0.26(0.17)$ & $0.22(0.20)$ & $0.17(0.10)$ & $0.10(0.09)$ & $0.11(0.10)$ & n.d. \\
\hline Min. /Max. & $0.08 / 1.24$ & $0.08 / 0.52$ & $0.08 / 1.02$ & $0.08 / 0.12$ & $0.08 / 0.16$ & n.d. \\
\hline
\end{tabular}

n.d. : not detected 
Table SI-4: continued

\begin{tabular}{|c|c|c|c|c|c|c|}
\hline cluster (hours) & C1 (307) & C2 (165) & C3 (179) & C4 (84) & C5 (88) & C6 (173) \\
\hline region of air mass origin & West & Northwest & Southwest & South & Northeast & East \\
\hline \multicolumn{7}{|c|}{ Organic aerosol factors in $\mu \mathrm{g} \mathrm{m}^{-3}$} \\
\hline HOA mean (median) & $0.08(0.07)$ & $0.07(0.06)$ & $0.11(0.10)$ & $0.07(0.05)$ & $0.08(0.05)$ & $0.13(0.13)$ \\
\hline Min. /Max. & $0.00 / 0.44$ & $0.00 / 0.26$ & $0.01 / 0.39$ & $0.01 / 0.53$ & $0.01 / 0.29$ & $0.01 / 0.32$ \\
\hline BBOA mean (median) & $0.37(0.29)$ & $0.30(0.25)$ & $0.44(0.34)$ & $0.27(0.23)$ & $0.26(0.13)$ & $0.53(0.53)$ \\
\hline Min. /Max. & $0.00 / 2.77$ & $0.03 / 1.27$ & $0.06 / 1.88$ & $0.09 / 0.90$ & $0.00 / 1.43$ & $0.00 / 1.27$ \\
\hline MO-OOA mean (median) & $0.65(0.50)$ & $0.44(0.27)$ & $1.32(1.47)$ & $1.49(1.47)$ & $1.15(0.44)$ & $2.52(2.47)$ \\
\hline Min. /Max. & $0.00 / 3.55$ & $0.02 / 2.87$ & $0.39 / 4.48$ & $0.53 / 2.53$ & $0.04 / 4.94$ & $0.06 / 5.58$ \\
\hline LO-OOA mean (median) & $0.91(0.74)$ & $0.55(0.53)$ & $2.32(1.76)$ & $2.54(2.44)$ & $0.87(0.85)$ & $1.46(1.41)$ \\
\hline Min. /Max. & $0.02 / 3.38$ & $0.04 / 1.94$ & $0.35 / 8.15$ & $0.82 / 5.33$ & $0.00 / 3.23$ & $0.26 / 3.83$ \\
\hline SV-OOA mean (median) & $0.36(0.28)$ & $0.39(0.25)$ & $0.87(0.76)$ & $0.60(0.53)$ & $0.57(0.39)$ & $1.06(0.96)$ \\
\hline Min. /Max. & $0.01 / 1.37$ & $0.02 / 1.94$ & $0.00 / 3.12$ & $0.02 / 2.22$ & $0.00 / 4.77$ & $0.02 / 5.26$ \\
\hline \multicolumn{7}{|c|}{ eBC aerosol factors in $\mu \mathrm{g} \mathrm{m}^{-3}$} \\
\hline eBC-HOA mean (median) & $0.12(0.11)$ & $0.13(0.11)$ & $0.18(0.15)$ & $0.13(0.10)$ & $0.12(0.08)$ & $0.22(0.21)$ \\
\hline Min. /Max. & $0.01 / 0.48$ & $0.03 / 0.73$ & $0.02 / 0.65$ & $0.02 / 0.89)$ & $0.01 / 0.48$ & $0.02 / 0.53$ \\
\hline eBC-BBOA mean (median) & $0.03(0.02)$ & $0.04(0.03)$ & $0.05(0.04)$ & $0.03(0.02)$ & $0.03(0.01)$ & $0.06(0.05)$ \\
\hline Min. /Max. & $0.00 / 0.15$ & $0.00 / 0.29$ & $0.00 / 0.19$ & $0.01 / 0.09$ & $0.00 / 0.15$ & $0.00 / 0.14$ \\
\hline eBC-MO-OOA mean (median) & $0.19(0.13)$ & $0.15(0.10)$ & $0.47(0.45)$ & $0.54(0.52)$ & $0.38(0.18)$ & $0.91(0,89)$ \\
\hline Min. /Max. & $0.00 / 0.77$ & $0.00 / 1.04$ & $0.00 / 1.48$ & $0.18 / 0.89$ & $0.01 / 1.59$ & $0.11 / 1.92$ \\
\hline
\end{tabular}

\section{References}

Canonaco, F., Crippa, M., Slowik, J. G., Prévôt, A. S. H., and Baltensperger, U.: SoFi, an IGOR-based interface for the efficient use of the generalized multilinear engine (ME-2) for the source apportionment: ME-2 application to aerosol mass spectrometer data, Atmos. Meas. Tech., 6, 3649-3661, doi:10.5194/amt-6-3649-2013, 2013.

Crippa, M., Canonaco, F., Lanz, V. A., Äijälä, M., Allan, J. D., Carbone, S., Capes, G., Ceburnis, D., Dall'Osto, M., Day, D. 245 A., DeCarlo, P. F., Ehn, M., Eriksson, A., Freney, E., Hildebrandt Ruiz, L., Hillamo, R., Jimenez, J. L., Junninen, H., Kiendler- 
Scharr, A., Kortelainen, A. M., Kulmala, M., Laaksonen, A., Mensah, A. A., Mohr, C., Nemitz, E., O'Dowd, C., Ovadnevaite, J., Pandis, S. N., Petäjä, T., Poulain, L., Saarikoski, S., Sellegri, K., Swietlicki, E., Tiitta, P., Worsnop, D. R., Baltensperger, U., and Prévôt, A. S. H.: Organic aerosol components derived from 25 AMS data sets across Europe using a consistent ME-2 based source apportionment approach, Atmos. Chem. Phys., 14, 6159-6176, doi:10.5194/acp-14-6159-2014, 2014.

250 Cubison, M. J., Ortega, A. M., Hayes, P. L., Farmer, D. K., Day, D., Lechner, M. J., Brune, W. H., Apel, E., Diskin, G. S., Fisher, J. A., Fuelberg, H. E., Hecobian, A., Knapp, D. J., Mikoviny, T., Riemer, D., Sachse, G. W., Sessions, W., Weber, R. J., Weinheimer, A. J., Wisthaler, A., and Jimenez, J. L.: Effects of aging on organic aerosol from open biomass burning smoke in aircraft and laboratory studies, Atmos. Chem. Phys., 11, 12049-12064, 10.5194/acp-11-12049-2011, 2011.

Engling, G., Carrico, C. M., Kreldenweis, S. M., Collett, J. L., Day, D. E., Malm, W. C., Lincoln, E., Hao, W. M., Iinuma, Y., and Herrmann, H.: Determination of levoglucosan in biomass combustion aerosol by high-performance anion-exchange chromatography with pulsed amperometric detection, Atmos. Environ., 40, S299-S311, doi:10.1016/j.atmosenv.2005.12.069, 2006.

Gnauk, T., Muller, K., van Pinxteren, D., He, L. Y., Niu, Y. W., Hu, M., and Herrmann, H.: Size-segregated particulate chemical composition in Xinken, Pearl River Delta, China: OC/EC and organic compounds, Atmos. Environ., 42, 6296-6309,

260 doi:10.1016/j.atmosenv.2008.05.001, 2008.

Iinuma, Y., Engling, G., Puxbaum, H., and Herrmann, H.: A highly resolved anion-exchange chromatographic method for determination of saccharidic tracers for biomass combustion and primary bio-particles in atmospheric aerosol, Atmos. Environ., 43, 1367-1371, doi:10.1016/j.atmosenv.2008.11.020, 2009.

Mohr, C., DeCarlo, P. F., Heringa, M. F., Chirico, R., Slowik, J. G., Richter, R., Reche, C., Alastuey, A., Querol, X., Seco, R., 265 Penuelas, J., Jimenez, J. L., Crippa, M., Zimmermann, R., Baltensperger, U., and Prevot, A. S. H.: Identification and quantification of organic aerosol from cooking and other sources in Barcelona using aerosol mass spectrometer data, Atmos. Chem. Phys., 12, 1649-1665, 2012.

Ng, N. L., Canagaratna, M. R., Jimenez, J. L., Zhang, Q., Ulbrich, I. M., and Worsnop, D. R.: Real-Time Methods for Estimating Organic Component Mass Concentrations from Aerosol Mass Spectrometer Data, Environ. Sci. Technol., 45, 910$270916,2011$.

Paatero, P.: The multilinear engine - A table-driven, least squares program for solving multilinear problems, including the nway parallel factor analysis model, J. Comput. Graph. Stat., 8, 854-888, doi:10.2307/1390831, 1999.

Poulain, L., Birmili, W., Canonaco, F., Crippa, e. a., Wu, Z. J., Nordmann, S., Spindler, G., Prévôt, A. S. H., Wiedensohler, A., and Herrmann, H.: Chemical mass balance of refractory particles $\left(\mathrm{T}=300^{\circ} \mathrm{C}\right)$ at the tropospheric research site Melpitz, 275 Germany, Atmos. Chem. Phys., 14, 10145-10162, doi:10.5194/acp-14-10145-2014, 2014.

Salcedo, D., Onasch, T. B., Dzepina, K., Canagaratna, M. R., Zhang, Q., Huffman, J. A., DeCarlo, P. F., Jayne, J. T., Mortimer, P., Worsnop, D. R., Kolb, C. E., Johnson, K. S., Zuberi, B., Marr, L. C., Volkamer, R., Molina, L. T., Molina, M. J., Cardenas, B., Bernabe, R. M., Marquez, C., Gaffney, J. S., Marley, N. A., Laskin, A., Shutthanandan, V., Xie, Y., Brune, W., Lesher, R., Shirley, T., and Jimenez, J. L.: Characterization of ambient aerosols in Mexico City during the MCMA-2003 campaign with

280 Aerosol Mass Spectrometry: results from the CENICA Supersite, Atmos. Chem. Phys., 6, 925 - 946, doi:10.5194/acp-6-9252006, 2006.

Tilgner, A., Schone, L., Brauer, P., van Pinxteren, D., Hoffmann, E., Spindler, G., Styler, S. A., Mertes, S., Birmili, W., Otto, R., Merkel, M., Weinhold, K., Wiedensohler, A., Deneke, H., Schrodner, R., Wolke, R., Schneider, J., Haunold, W., Engel, A., Weber, A., and Herrmann, H.: Comprehensive assessment of meteorological conditions and airflow connectivity during 285 HCCT-2010, Atmos. Chem. Phys., 14, 9105-9128, 10.5194/acp-14-9105-2014, 2014.

Ulbrich, I. M., Canagaratna, M. R., Zhang, Q., Worsnop, D. R., and Jimenez, J. L.: Interpretation of organic components from Positive Matrix Factorization of aerosol mass spectrometric data, Atmos. Chem. Phys., 9, 2891-2918, doi:10.5194/acp-9-28912009, 2009. 